\title{
ALIENABLE AND INALIEANABLE NOUNS IN WANO
}

\author{
Willem Burung* \\ University of Oxford $\mid$ St. Catherine's College \\ willem.burung@stcatz.ox.ac.uk|wburung@hotmail.com
}

\begin{abstract}
This paper describes structural and distributional properties of alienable and inalienable nouns in Wano, a Trans-New Guinea language spoken in Papua by about 7,000 native speakers. I define differences between alienable and inalienable nouns in $\$ 2$, where it will be apparent that they can be distinguished in terms of their (i) nominal generalisation (\$2.1), (ii) lexical forms (\$2.2), (iii) plurality coding (\$2.3), (iv) possessive constructions (\$2.4), and (v) head-role in a clause (\$2.5). Alienable nouns are described in $\$ 3$. Then in $\$ 4$, I will demonstrate that inalienable nouns are: (i) restricted on vowel-initial words, and (ii) there is a clear morphosyntax-semanticspragmatics interface reflected in kin terminologies. The kin term for 'child', for instance, is distinguished with respect to the sex of parents. In expressing the ownership of a child, a father will use the word nabut for the English 'my child' (inflection of: \{ $n$ abut $\} \backslash 1$ s-child.of.male $\backslash$ ) and a mother will use nayak 'my child' (inflection of: \{n-ajak\} $\backslash \backslash$ s-child.of.female $\backslash$. Terms for kinship relations, body parts, cultural items, and experiential events are inalienably coded. Finally, words that are inalienably marked will be presented in $\$ 5$.
\end{abstract}

Keywords: Wano, alienable nouns, inalienable nouns, nabut, nayak

\begin{abstract}
Abstrak
Makalah ini membahas properti struktural dan distribusional dari nomina alienable dan inalienable dalam bahasa Wano, salah satu bahasa Trans-New Guinea di Papua dengan penutur asli yang berjumlah kurang-lebih 7.000 orang. Dalam $§ 2$, penulis merumuskan perbedaan antara nomina alienable dan inalienable, di mana akan nampak jelas bahwa keduanya dapat dibedakan berdasarkan (i) generalisasi nominalnya (\$2.1), (ii) bentuk leksikalnya (§2.2), (iii) penanda jamaknya (§2.3), (iv) konstruksi posesifnya (\$2.4), dan tipologi head-role-nya dalam klausa (\$2.5). Nomina alienable dibahas dalam §3. Dalam $\S 4$, akan nampak bahwa nomina inalienable: (i) terbatas pada kata-kata yang didahului oleh bunyi vokal, dan (ii) mencerminkan keterkaitan timbal-balik antara morfosintaks, semantik dan pragmatik, di antaranya dalam kosa-kata kekerabatan. Misalnya, istilah untuk 'anak' dibedakan berdasarkan jenis kelamin orangtuanya. Untuk mengungkapkan kepemilikan anak, penutur laki-laki memakai kata nabut untuk 'anak saya' (infleksi dari \{n-abut\} 11s-anak.dari.laki-lakil), sedangkan perempuan menggunakan kata nayak untuk 'anak saya' (infleksi dari \{n-ajak\} \1s-anak.dari.perempuanl). Kosakata yang merujuk pada istilah-istilah kekerabatan, anggota tubuh, benda-benda budaya dan experiential events termasuk dalam nomina inalienable. Selain itu, masih ada kosakata yang ditandai sebagai nomina inalienable namun bukan bagian dari rujukan istilahistilah tersebut di atas; kosa-kata seperti ini akan diuraikan dalam §5.
\end{abstract}

Kata kunci: Wano, nomima alienable, nomina inalienable, nabut, nayak 


\section{INTRODUCTION}

This paper describes structural and distributional properties of alienable and inalienable nouns in Wano. \$2 defines the differences between alienably possessed nouns and inalienably possessed nouns, $\S 3$ provides a description of alienable nouns, $\S 4$ presents a description of inalienable nouns, $\$ 5$ describes inalienably marked words.

Wano is a Trans-New Guinea language spoken in Papua, ${ }^{i}$ a member of the Dani family, which also includes Dani, Walak and Nggem. It is spoken by approximately 7,000 native speakers (Burung 2007b, 2017). The number of speakers is given as 3.000 in Larson (1977:7), 1.500 in Foley (1986:239) and 3.500 in Grimes' Ethnologue (1996). Early works that supply some data on Wano are (i) Swadesh wordlist by Larson (1977, Iratoi, Turumo), (ii) Survey report of Walker and Moxness (1988), on their visit to Iratoi, Turumo, Dagai, Nggweri and Lumo, and (iii) Burung's archive (1993, 1994, 1997, 2001, 2002, 2003, 2004, 2005, 2007a, 2007b, 2009, 2013) and recent work (2017). ii

Wano allows both free and bound pronouns, each with a set of six members expressing person/number $(1,2,3 / \mathrm{sg}, \mathrm{pl})$ distinction. There is no inclusive-exclusive distinction. In the free pronouns, there is a correlation of the vocalic phoneme /a/ with singular and /i/ with plural. Both free and bound pronouns have the correlation of the consonantal phoneme $/ \mathrm{n} /$ with first person, $/ \mathrm{k} /$ with second person and the zero morpheme (indicated by the $\varnothing$ symbol) with the third person. Whilst the vocalic phoneme is not found in the set of inalienable bound pronouns, because all inalienable forms start with a vowel, the plural marker is iny $\{$-in\} which is immediately suffixed to the person prefixes. This is outlined in Table 1:

Table 1. Wano Personal Pronouns

\begin{tabular}{|c|c|c|c|c|c|c|}
\hline & SG & & & PL & & \\
\hline & 1 & 2 & 3 & 1 & 2 & 3 \\
\hline FREE & $a n$ & kat & $a t$ & nit & kit & it \\
\hline BOUND & $\begin{array}{l}n \\
\{n-\}\end{array}$ & $\begin{array}{l}k \\
\{k-\}\end{array}$ & $\begin{array}{l}\text { zero } \\
\{\varnothing-\}\end{array}$ & $\begin{array}{l}\text { ninny } \\
\{\text { nin- }\}\end{array}$ & $\begin{array}{l}\text { kiny } \\
\text { kin- }\end{array}$ & $\begin{array}{l}\text { iny } \\
\{\text { in- }\}\end{array}$ \\
\hline
\end{tabular}

This set of personal pronouns do not vary in accordance with grammatical function. In general, free pronouns may take on the role of transitive Subject (A), intransitive Subject (S), transitive Object (DO), or Beneficiary (IO/BEN). Bound pronouns may function as (i) DO/IO/BEN, or (ii) possessor (POSS). The internal structure of nouns includes possessive prefixes, plural suffixes (PL) and locative suffixes (LOC). In this paper, I will discuss only the first two mentioned (\$2).

Figure 1 summarizes the typology of possessive nouns in Wano, whereby nouns are divided into alienably possessed nouns (APN) and inalienably possessed nouns (IPN) - see Burung (2017: §s3.2-5 and §7.2). 
Figure 1. Typology of possessive nouns in Wano

\begin{tabular}{|c|c|c|c|}
\hline & \multicolumn{2}{|c|}{ NOUNS } & \\
\hline & & \multirow{2}{*}{\multicolumn{2}{|c|}{$\begin{array}{c}2 \\
\text { INALIENABLE }\end{array}$}} \\
\hline \multicolumn{2}{|c|}{ ALIENABLE } & & \\
\hline \multirow{2}{*}{$\begin{array}{l}2.1 \\
2.1\end{array}$} & 22 & 23 & 2.4 \\
\hline & KINSHIP & BODY PARTS & EXPERIENTIAL EVENTS \\
\hline 2.3 .1 & \begin{tabular}{l|l}
2.3 .2 \\
\end{tabular} & & \\
\hline SOLID & LIQUID & 2.4 .1 & 2.4 .2 \\
\hline & & COGNITION & PHYSIOLOGY \\
\hline
\end{tabular}

Further subdivisions of inalienably possessed nouns are lexical items denoting cultural and kinship terms, as well as those terms for body parts and experiential events. Terms for body parts are divided into solid and liquid types of properties, while those for experiential events are categorised into terms connected with the cognitive sphere and physiological domain. In this study, hereafter, I will shorten the term alienably possessed nouns to alienable nouns, and inalienably possessed nouns to inalienable nouns while retaining their abbreviations: APN and IPN. I will first distinguish these two categories of nouns.

\section{ALIENABILITY AND INALIENABILITY}

The differences between alienable nouns and inalienable nouns in Wano can be explained as follows.

\subsection{Nominal generalisation}

The first distinction we can make between alienable nouns and inalienable nouns is by their nominal generalisation. Regarding the abstract-concrete relation, abstract nouns are not found as alienable nouns. Concerning the common-proper relation, proper nouns are not attested as inalienable nouns. This is outlined in Table $2-$ for the abbreviations, see endnote ii.

Table 2. Nominal generalisation of alienable nouns (APN) and inalienable nouns (IPN) in Wano

\begin{tabular}{l|cccccc}
\multirow{2}{*}{ NOUNS } & CM & PN & MN & CN & AN & CON \\
\cline { 2 - 7 } APN & $\checkmark$ & $\checkmark$ & $\checkmark$ & $\checkmark$ & N/A & $\checkmark$ \\
IPN & $\checkmark$ & N/A & $\checkmark$ & $\checkmark$ & $\checkmark$ & $\checkmark$
\end{tabular}

Referring to Table 2, the alienable yugum 'stone', and the inalienable ova 'his-father' are examples of common, countable and concrete nouns. In terms of mass nouns, we have examples like $i$ 'water' for the alienable nouns, and adian 'his-blood' for the inalienable nouns. For the abstract nouns in Wano, there are only examples of inalienable nouns, such as abua 'his-love' and anduk 'his-pain'. Lastly, the proper nouns can only be expressed as alienable nouns, e.g. mirib is a clan name in Wano. These examples are outlined in: 


\begin{tabular}{|c|c|c|c|c|c|c|}
\hline \multirow{2}{*}{$\begin{array}{l}\text { NOUNS } \\
\text { Alienable: }\end{array}$} & $\mathrm{CM}$ & PN & $\mathrm{MN}$ & $\mathrm{CN}$ & AN & $\mathrm{CON}$ \\
\hline & & & & & & \\
\hline yugum 'stone' & $\checkmark$ & & & $\checkmark$ & & $\checkmark$ \\
\hline$i \quad$ 'water' & & & $\checkmark$ & & & \\
\hline mirib a clan name & & $\checkmark$ & & & & \\
\hline Inalienable: & & & & & & \\
\hline 'his-father' & $\checkmark$ & & & $\checkmark$ & & $\checkmark$ \\
\hline 'his blood' & & & $\nabla$ & & & \\
\hline abua 'his-love' & & & & & & \\
\hline
\end{tabular}

\subsection{Lexical forms}

The second way to distinguish alienable nouns and inalienable nouns is by looking at their lexical forms. Alienable nouns are both consonant-initial (henceforth: C-initial) and vowelinitial (V-initial), like tavo 'tobacco' and abui 'possum' (2a, b). Inalienable nouns are restricted to vowel initial, such as abut 'his-child' and indiq 'his-name' (2c, d).

\section{Consonant-initial}

a. Alienable nouns

1. tavo 'tobacco'

c. Inalienable nouns:

2. yugum 'stone'

\section{Vowel-initial}

b. Alienable nouns:
1. abui
'possum'

2. indu

'fire'

d. Inalienable nouns:

1. abut 'his-child'
2. indiq 'his-name'

\subsection{Plurality coding}

The third way to differentiate alienable nouns from inalienable nouns is by observing the way they are pluralised. They are different in their plural coding, with regards to common, countable and concrete nouns. The quantity of alienable nouns is coded by means of nominal modification, i.e. numeral modifier in the [HEAD-MODIFIER] structure, as shown in (3a), whilst inalienable nouns are pluralised by suffixation: [ROOT-plural suffix], as given in (3b).

$$
\begin{array}{ll}
\multicolumn{2}{c}{\text { Alienable nouns: }} \\
\text { a. yugum mbere } & \text { 'two stones' } \\
\text { a'. *yugum-vi } & \\
\text { Inalienable nouns: } & \\
\text { b. ova-vi } & \text { 'his-fathers' } \\
\text { b'. } \quad \text { ova mbere } &
\end{array}
$$

The inalienable noun plural suffixes are: wi $\{-w i\} \sim v i\{-v i\}$ 'PL', when the noun is a vowel-final root, otherwise $i\{-\mathrm{i}\}$ 'PL', as can be seen in (3c) and (4), for example:

\section{a. Vowel-final Root:}

SINGULAR
are
$\varnothing$-ate
3s-uncle
'his/her uncle'

\author{
PLURAL \\ arevi \\ $\emptyset$-ate-vi \\ 3s-uncle-PL \\ 'his/her uncles'
}


b. Consonant-final Root:

$\begin{array}{ll}\text { SINGULAR } & \text { PLURAL } \\ \text { abut } & \text { aburi } \\ \varnothing \text {-abut } & \varnothing \text {-abut-i } \\ \text { 3s-child.oM } & \text { 3s-child.oM-PL } \\ \text { 'his child' } & \text { 'his children' } \\ \text { [lit. } \text { 'his child.of.male'] } & \text { [lit. 'his children.of.male'] }\end{array}$

Note that the term for 'child' in (4b) is different for a female possessor in (5), where the plural form is suppletive with the plural morpheme.

(5)

SINGULAR
ayak
ø-ajak
3s-child.oF
'her child'
[lit. 'her child.of.female']

\author{
PLURAL \\ acui \\ $\varnothing$-atjui \\ 3s-child.oF.PL \\ 'her children' \\ [lit. 'her children.of.female']
}

A detailed discussion on the different forms and their uses of abut 'his child' and ayak 'her child' is given in $\S 4.2$.

\subsection{Possessive constructions}

Possessive constructions are another way to distinguish between alienable nouns and inalienable nouns. Whilst alienable nouns are those that do not require possessive marking, inalienable nouns cannot occur without possessive marking, cf. $\S 3$ and $\S 4$.

In Wano, the possessive markers for alienable nouns are prefixal with vowel-insertion, as illustrated in (6) and (7a-c). They are: $n \boldsymbol{V}\{\mathrm{nV}-\} \backslash 1 \mathrm{~s}-\backslash$ 'my-', $k \boldsymbol{V}\{\mathrm{kV}-\} \backslash 2 \mathrm{~s}-\backslash$ 'your.sg', $\boldsymbol{V}\{\mathrm{V}-\}$

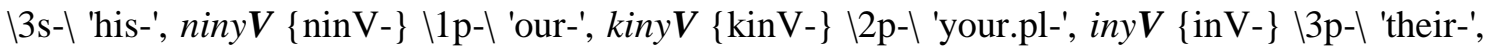
cf. Table 3a-a'. The possessive markers for inalienable nouns are prefixal bound pronouns since they involve bound prefixes as apparent in (6) and (7d-f). They are: $\boldsymbol{n}\{\mathrm{n}-\} \backslash 1 \mathrm{~s}-\backslash$ 'my-', $\boldsymbol{k}\{\mathrm{k}-\}$ $12 \mathrm{~s}-\backslash$ 'your.sg-', zero $\{\varnothing-\} \backslash 3 \mathrm{~s}-\backslash$ 'his-', niny $\{$ nin- $\} \backslash 1 \mathrm{p}-\backslash$ 'our-', kiny $\{\mathrm{kin}-\} \mid 2 \mathrm{p}-\backslash$ 'your.pl-' and iny $\{$ in- $\}$ 13p-I 'their-', cf. Table 3b.

Furthermore, the inflections of the plural forms are: (i) niny $\{$ nin- $\}<\{$ n-in- $\} \backslash 1 \mathrm{~s}-\mathrm{PL}-1$ 'my-PL-', (ii) kiny $\{$ kin- $\}<\{$ k-in- $\} \backslash 2 \mathrm{~s}-\mathrm{PL}-\mathrm{I}$ 'your.sg-PL-' and (iii) iny $\{$ in- $\}<\{\varnothing$-in- $\}$ 13s-PL- 'hisPL-'. Henceforth, I shall present them as single morphemes for the sake of simplicity and practicality. This is outlined in Table 3:

Table 3. Bound possessive pronouns in Wano

\begin{tabular}{|c|c|c|}
\hline \multicolumn{3}{|c|}{ a. Consonant-initial alienable nouns } \\
\hline SINGULAR & & \\
\hline 1 & 2 & 3 \\
\hline$n V C$ & $k V C$ & $V C$ \\
\hline$\{\mathrm{nV}-\mathrm{C}\}$ & $\{\mathrm{kV}-\mathrm{C}\}$ & $\{\mathrm{V}-\mathrm{C}\}$ \\
\hline$\backslash 1 \mathrm{~s}-\rfloor$ & $12 \mathrm{~s}-1$ & $13 s-1$ \\
\hline 'my-' & 'your.sg-' & 'his-' \\
\hline
\end{tabular}

\begin{tabular}{|lll|}
\hline PLURAL & & \\
1 & 2 & 3 \\
ninyVC & kinyVC & inyVC \\
$\{$ ninV-C $\}$ & $\{$ kinV-C $\}$ & $\{$ inV-C $\}$ \\
$\backslash 1 \mathrm{p}-1$ & $12 \mathrm{p}-1$ & $13 \mathrm{p}-1$ \\
'our-' & 'your.pl-' & 'their-' \\
\hline
\end{tabular}


a'. Vowel-initial alienable nouns

$\begin{array}{lll}\text { SINGULAR } & & \\ 1 & 2 & 3 \\ n V V & k V V & V V \\ \{\mathrm{nV}-\mathrm{V}\} & \{\mathrm{kV}-\mathrm{V}\} & \{\mathrm{V}-\mathrm{V}\} \\ \lfloor 1 \mathrm{~s}-\backslash & 12 \mathrm{~s}-\backslash & 13 \mathrm{~s}-\backslash \\ \text { 'my-' } & \text { 'your.sg-' } & \text { 'his-' }\end{array}$

\section{b. Inalienable nouns}

\begin{tabular}{|lll|}
\hline SINGULAR & & \\
1 & 2 & 3 \\
$n$ & $k$ & zero \\
$\{\mathrm{n}-\}$ & $\{\mathrm{k}-\}$ & $\{\varnothing-\}$ \\
$\backslash 1 \mathrm{~s}-1$ & 12s- & Is- -1 \\
'my-' & 'your.sg-' & 'his-' \\
& & \\
\hline
\end{tabular}

The examples are:

(6)

Alienable nouns:

$\begin{array}{lll}\text { a. } & \text { e-tavo } & \text { 'his tobacco' } \\ \text { a' } & \text { ne-tavo } & \text { 'my tobacco' } \\ \text { b. } & e \text {-abui } & \text { 'his possum' } \\ \text { b'. } & \text { ne-abui } & \text { 'my possum' }\end{array}$

Inalienable nouns:
c. $\varnothing$-ova
'his-father'
c'. n-ova
'my-father'
d. $\quad$-abut
'his-child'
d'. n-abut

\begin{tabular}{|lll|}
\hline PLURAL & & \\
1 & 2 & 3 \\
ninyVV & kinyVV & inyVV \\
$\{$ ninV-V $\}$ & $\{$ kinV-V $\}$ & $\{$ inV-V $\}$ \\
$\backslash 1 \mathrm{p}-1$ & $12 \mathrm{p}-1$ & $13 \mathrm{p}-1$ \\
'our-' & 'your.pl-' & 'their-' \\
\hline
\end{tabular}

\begin{tabular}{|lll|}
\hline PLURAL & & \\
1 & 2 & 3 \\
niny & kiny & iny \\
$\{$ nin- $\}$ & $\{$ kin- $\}$ & $\{$ in- $\}$ \\
$\backslash 1 \mathrm{p}-1$ & $12 \mathrm{p}-1$ & $13 \mathrm{p}-1$ \\
'our-' & 'your.pl-' & 'their-' \\
\hline
\end{tabular}

[Table 3a]

[Table 3a']

[Table 3b]

The possessive expression of alienable nouns and inalienable nouns can also be coded by using the inalienable ene 'his-belonging', as illustrated in:

\begin{tabular}{|c|c|c|c|c|c|}
\hline \multicolumn{3}{|c|}{ Alienable nouns: } & \multicolumn{3}{|c|}{ Inalienable nouns: } \\
\hline \multirow[t]{4}{*}{ a. } & tavo & ene & c. & ova & ene \\
\hline & tavo & $\emptyset$-ene & & $\varnothing$-ova & $\emptyset$-ene \\
\hline & tobacco & 3s-belonging & & 3 s-fathe & 3s-belonging \\
\hline & 'tobacco & & & 'father o & \\
\hline \multirow[t]{4}{*}{ b. } & tavo & nene & d. & nova & nene \\
\hline & tavo & n-ene & & n-ova & n-ene \\
\hline & tobacco & 1s-belonging & & 1s-fathe & 1s-belonging \\
\hline & 'tobacco & nine' & & 'father o & \\
\hline
\end{tabular}

The syntactic expression in (7) is also found for the difference between cultural items and body part nouns as we can see later in the example given in (21) in \$4.1. Meanwhile, Figure 2 compares the structures of alienable and inalienable nouns. 
Figure 2. Structures of alienable and inalienable nouns

ALIENABLE NOUNS

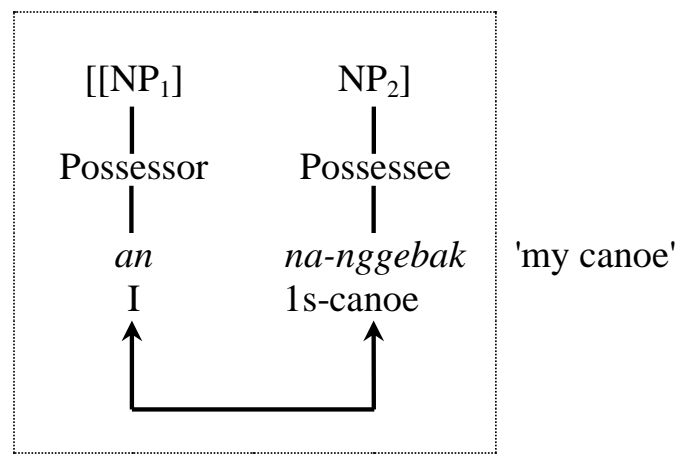

INALIENABLE NOUNS

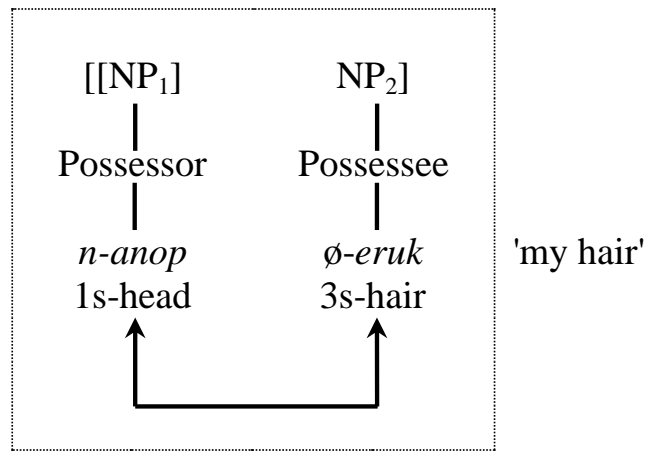

Figure 2 shows an identical NP structure for alienable and inalienable nouns. Here, an 'I' and nanop 'my head' take the role of possessors, whilst nggebak 'canoe' and eruk 'his hair' are the possessees. There is agreement in terms of person/number. In alienable nouns, nggebak 'canoe' is ' $3 \mathrm{~s}$ ' but should bear the prefix $n a$ - '1s (not $a$ for ' $3 \mathrm{~s}$ ') because the possessor an is ' $1 \mathrm{~s}$ '. In inalienable nouns, eruk is ' $3 \mathrm{~s}$ ' and should bear the zero prefix ' $3 \mathrm{~s}$ ' since the possessor nanop is ' $3 \mathrm{~s}$ '. Furthermore, $\mathrm{NP}_{1}$ in both types of possession is not obligatory since nanggebak and eruk alone have phrasal meanings 'my canoe' and 'his-hair'. The difference is that the root of alienable nouns, in this instance, nggebak 'canoe', is not a vowel-initial alienable noun, while the root of inalienable nouns, i.e. eruk 'his-hair' is a vowel-initial word. This is consistent with our claim earlier that inalienable nouns are vowel-initial words, whereas alienable nouns are not necessarily vowel-initial words. In fact, almost all alienable nouns are consonant-initial. The paradigms in (8) show that alienable nouns require vocalic insertion to mark possession, as nggebak 'canoe' becomes na-nggebak 'my-canoe', while this is not required for inalienable nouns.

A distinctive paradigm of alienable and inalienable nouns

\begin{tabular}{|c|c|c|c|c|}
\hline & ALIENABLE & OUNS & INALIENAB & IOUNS \\
\hline & Root: nggebak & anoe' & Root: eruk'h & \\
\hline & SINGULAR & PLURAL & SINGULAR & PLURAL \\
\hline a. & nanggebak & ninyanggebak & neruk & ninyeruk \\
\hline & na-nkebak & nina-nkebak & n-etuk & nin-etuk \\
\hline & 1s-canoe & 1p-canoe & 1s-hair & 1p-hair \\
\hline & 'my canoe' & 'our canoe' & 'my hair' & 'our hair' \\
\hline b. & kanggebak & kinyanggebak & keruk & kinyeruk \\
\hline & ka-nkebak & kina-nkebak & k-etuk & kin-etuk \\
\hline & 2s-canoe & 2p-canoe & 2s-hair & 2p-hair \\
\hline & 'your.sg canoe & 'your.pl canoe' & 'your.sg hair' & 'your.pl hair' \\
\hline c. & anggebak & inyanggebak & eruk & inyeruk \\
\hline & a-nkebak & ina-nkebak & ø-etuk & in-etuk \\
\hline & 3s-canoe & 3p-canoe & 3s-hair & 3p-hair \\
\hline & 'his canoe' & 'their canoe' & 'his hair' & 'their hair' \\
\hline
\end{tabular}


Since the examples in (8) involve a consonant-initial alienable noun, the difference is apparent between these two types of nouns. Let us now consider (9) that has a vowel-initial alienable noun. There, we contrast the alienable abui 'possum' to the inalienable abut 'his-child'. Note: oM $=$ of male.

A distinctive paradigm of alienable and inalienable nouns

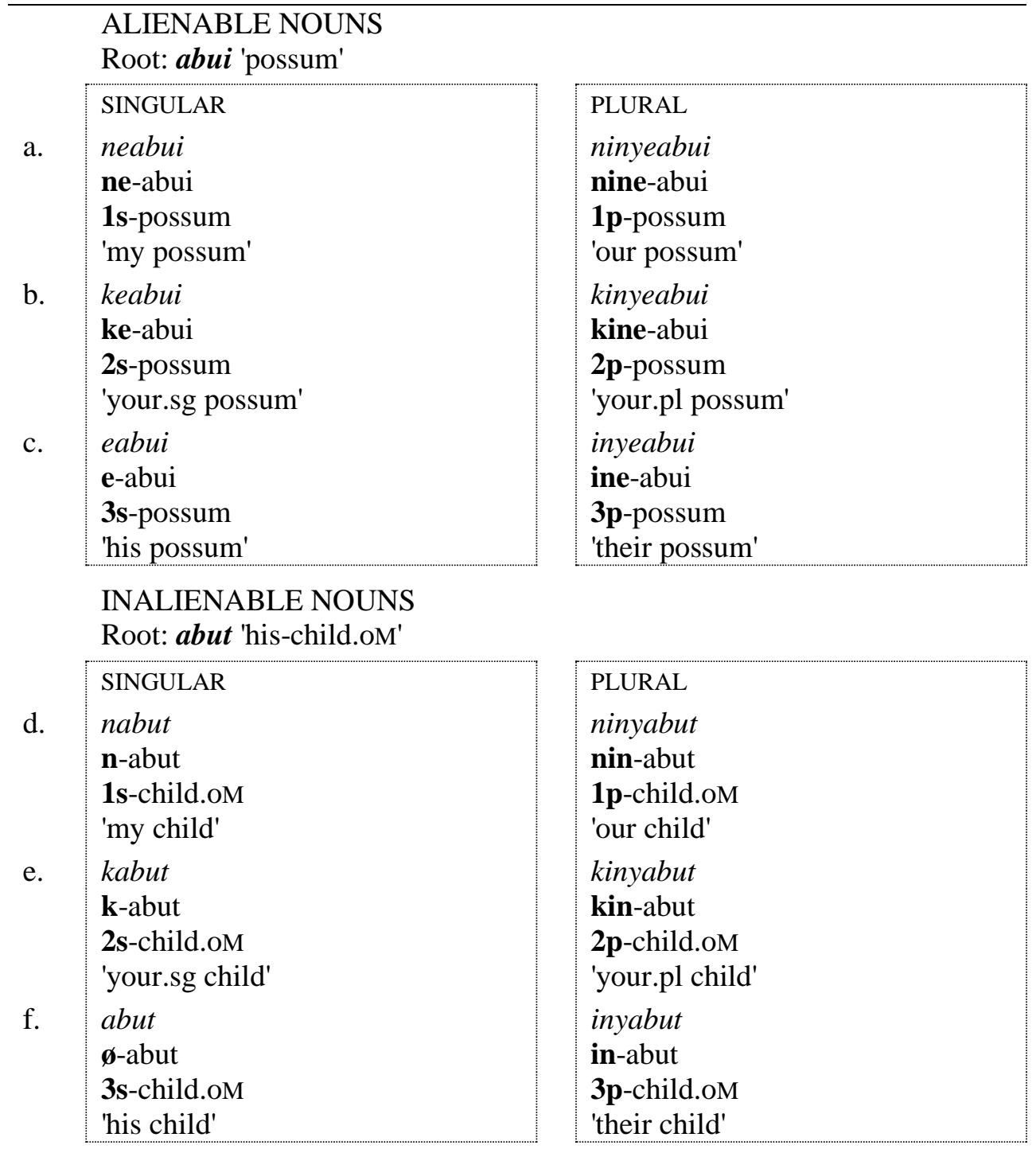

In $(9 \mathrm{a}-\mathrm{c})$, we note that there is a vowel-insertion process to mark possession of the alienable abui 'possum', which is eabui \{e-abui\} 'his-possum' (9c). In (9d-f), however, there is no need for the vowel-insertion process to possess the inalienable abut 'his-child', as is apparent in (9f), i.e. abut $\{\varnothing$-abut $\}$ 'his-child'. In terms of their plural coding (cf. \$2.3), we cannot have *abuivi \{abui-vi\} for 'possums', but we can have aburi $\{\varnothing$-abut-i\} for 'his-children'. In this instance, the head-modifier agreement shows a clear distinction between alienable nouns and inalienable nouns. In (10a-b), there is no head-modifier agreement in terms of number in the alienable 
nouns. In (10a'-b'), however, there is head-modifier agreement in the inalienable nouns, cf. (3c) as well.

\begin{tabular}{|c|c|c|c|}
\hline \multicolumn{4}{|c|}{ Vowel-initial alienable nouns: abui 'possum' } \\
\hline a. & $\begin{array}{l}\text { abui } \\
\text { possum }\end{array}$ & $\begin{array}{l}\text { mbere } \\
\text { two }\end{array}$ & 'two possums' \\
\hline b. & $\begin{array}{l}\text { *abuivi }\{\text { abui-vi }\} \\
\text { Possums }\end{array}$ & $\begin{array}{l}\text { mbere } \\
\text { two }\end{array}$ & N/A \\
\hline \multicolumn{4}{|c|}{ Inalienable nouns: abut 'his-child.oM' } \\
\hline$a^{\prime}$ & $\begin{array}{l}\text { *abut } \\
\text { his-child.oM }\end{array}$ & $\begin{array}{l}\text { mbere } \\
\text { two }\end{array}$ & N/A \\
\hline$b^{\prime}$. & $\begin{array}{l}\text { aburi }\{\varnothing \text {-abut-i }\} \\
\text { his-children.oM }\end{array}$ & $\begin{array}{l}\text { mbere } \\
\text { two }\end{array}$ & 'his two children' \\
\hline
\end{tabular}

The following is a list of some vowel-initial alienable nouns in Wano.

$$
\text { Vowel-initial alienable nouns: }
$$

$\begin{array}{lll}\text { a. } & \text { akomi } & \text { 'women' } \\ \text { b. } & \text { akut } & \text { 'already harvested field' } \\ \text { c. } & \text { ambo } & \text { 'k.o. tree' } \\ \text { d. } & \text { en } & \text { 'sugar cane' } \\ \text { e. } & \text { ico } & \text { 'k.o. tree' } \\ \text { f. } & \text { indu } & \text { 'fire' or 'flame' } \\ \text { g. } & \text { inyo } & \text { 'bread-fruit' } \\ \text { h. } & \text { ijom } & \text { 'grasshopper' } \\ \text { i. } & \text { ongga } & \text { 'k.o. palm' } \\ \text { j. } & \text { ap } & \text { 'man', 'person', 'people' } \\ \text { k. } & \text { uyak } & \text { 'hornbill' } \\ \text { l. } & \text { ut } & \text { 'moss' }\end{array}$

For the complete list, see Burung (2017: appendix 2). Further description of alienable nouns is detailed in $\S 3$, and that of inalienable nouns is given in $\S 4$.

\subsection{Grammatical relation}

Alienable nouns and inalienable nouns can be distinguished in terms of their grammatical relation. In this case, while both alienable and inalienable nouns may be the head of a phrase, only the latter can be the head of a clause. In a noun phrase, for instance, ap kode \{ap kode\} 'old man' constitutes a [HEAD-MODIFIER] structure where the alienable noun is the head. Likewise, eruk kik $\{\varnothing$-etuk kik\} 'his-dirty-hair' for the same structure. Thus, in a noun phrase, both alienable nouns and inalienable nouns may be the head.

(12) Alienable nouns:

$\begin{array}{lll} & \text { HEAD } & \text { MODIFIER } \\ \text { a. } & a p & \text { kode } \\ & \text { man } & \text { old } \\ & \text { '(an) old man' }\end{array}$


Inalienable nouns:

$\begin{array}{lll} & \text { HEAD } & \text { MODIFIER } \\ \text { b. } & \text { eruk } & \text { kik } \\ & \varnothing \text {-etuk } \quad \text { kik } \\ & \text { 3s-hair } & \text { dirty } \\ & \text { 'his dirty hair' }\end{array}$

In a clause, however, whilst both types of nouns take the argument (ARG) roles, only inalienable nouns are permitted to function as the head of the clause. I will briefly discuss this in $\$ 4.4$ on the notion of Experiential Events. A detailed discussion is given in Burung (2017: §7.2). I will now explore these two categories of nouns in turn.

\section{ALIENABLE NOUNS}

In the previous sections, i.e. $\S 1$ and $\S 2$, I established the differences between alienable nouns and inalienable nouns. Regarding their possessiveness, I pointed out that lexical forms are one of the ways to distinguish alienable nouns and inalienable nouns. The inalienable nouns are restricted to the vowel-initial (V-initial) form, while the alienable nouns are both consonantinitial (C-initial) and V-initial. In terms of vowel insertion for the C-initial alienable nouns, except for the high back vowel, all other vowels can be inserted. However, it is not always easy to predict which vowel a possessee can take. The following guideline may suffice.

When the initial consonant of the posseesee nouns is either an alveolar or palatal, the inserted vowel is $\boldsymbol{e}$. Note that $\boldsymbol{e}$ is in variation with $\boldsymbol{i}$ in this case.
a. $\frac{\text { ROOT }}{\text { tavo }}$
$\underline{i \sim e-R O O T}$
b. yanggwi
eravo \{e-tavo\} $13 \mathrm{~s}$-tobaccol
'his tobacco'
eyanggwi $\{\mathrm{e}-\mathrm{jankwi}\} \backslash 3 \mathrm{~s}-\mathrm{cock}$ atoo\}
'cockatoo'
'his cockatoo'
c. yavuk
'planted field'
eyavuk \{e-javuk\} |3s-planted field
d. yarak
'his planted field'
'harvested field'
eyarak $\{\mathrm{e}$-jatak\} 13 s-harvested field $\backslash$
'his harvested field'

When the initial consonant is bilabial, we have $\boldsymbol{o}$.
$\frac{\mathrm{ROOT}}{\text { bato }}$
'corn'
b. mboid
'potato'
c. mbit
'moon'
d. poiya
'sun'
o-ROOT
obato \{o-bato $\backslash 3 \mathrm{~s}-\mathrm{corn} \backslash$
'his corn'
omboid \{o-mboid\} |3s-potato'।
'his potato'
ombit \{o-mbit\} \3s-moon'\
'his moon'
opoiya \{o-poija\} $\mid 3 \mathrm{~s}-$ sun'।
'his sun'

Finally, we will have $\boldsymbol{a}$ elsewhere.
$\begin{array}{ll}\text { a. } & \frac{\mathrm{ROOT}}{\text { kede }} \\ \text { 'rattan' }\end{array}$
$\underline{a-\mathrm{ROOT}}$
agede \{a-kede\} \3s-rattan\
'his rattan' 


\begin{tabular}{|c|c|c|}
\hline b. & $\begin{array}{l}\text { ndok } \\
\text { 'reed' }\end{array}$ & $\begin{array}{l}\text { andok }\{\text { a-ndok }\} \backslash 3 \mathrm{~s}-\text { reed } \backslash \\
\text { 'his reed' }\end{array}$ \\
\hline c. & $\begin{array}{l}\text { nggidivi } \\
\text { 'lemon' }\end{array}$ & $\begin{array}{l}\text { anggidivi }\{\text { a-nkidivi\} } \backslash 3 \text { s-lemon } \backslash \\
\text { 'his lemon' }\end{array}$ \\
\hline d. & $\begin{array}{l}\text { nggewo } \\
\text { 'dog' }\end{array}$ & $\begin{array}{l}\text { anggewo }\{\text { a-nkewo }\} \backslash 3 \text { s-nkewo } \\
\text { 'his dog' }\end{array}$ \\
\hline e. & $\begin{array}{l}\text { wom } \\
\text { 'pig' }\end{array}$ & \begin{tabular}{l} 
anggwom $\{$ a-nkwom $\} \backslash 3$ s-pig\} $\\
{\text { 'his pig' }}$ \\
\hline
\end{tabular}
\end{tabular}

Except for the two nouns ap 'man' and kwa 'woman', common nouns may be inflected to be possessed, as was illustrated above. There is no plural form for ap 'man' as opposed to its counterpart kwa 'woman' which has the plural akomi 'women', a fossilized form that is derived from an inflection of ap $\{\mathrm{ap}\} \backslash \mathrm{ap} \backslash$ 'man' + komi \{kom-i\} lyam-PL 'yams'; literally: 'A person who deals with yams or mealffood.' Furthermore, reduplication of ap 'man' and $k w a$ 'woman' is not possible to express plurality: *ap-ap $\{\mathrm{ap}$ ap $\}$, *kwa-gwa $\{\mathrm{kwa} \sim \mathrm{kwa}\}$, while numerals are allowed: ap mbere \{ap mpete\} Iman two 'two men', and kwa kena \{kwa kena\} Iwoman threel 'three women'. This is outlined in:

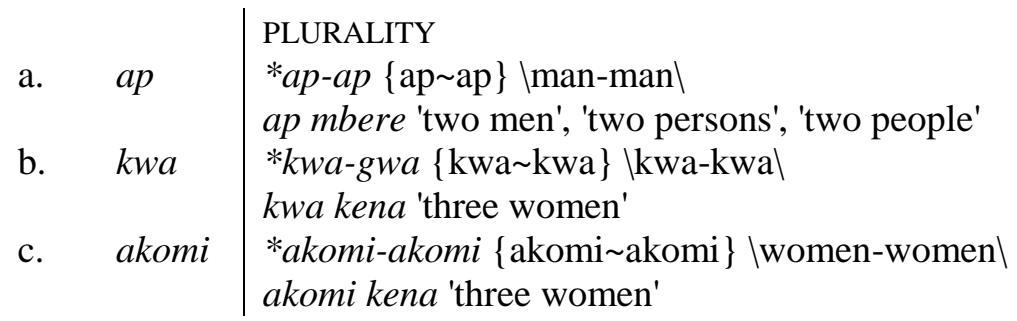

Numerals like yedogo 'many' can modify ap 'man', as in ap yedogo \{ap jedoko\} Iman many\ 'many men' or 'many people'. This is not possible for kwa 'woman', but akomi 'women' instead. Thus *kwa yedogo, but akomi yedogo \{akomi jedoko\} \women many 'many women'.

$$
\begin{aligned}
& \begin{array}{l|l}
\text { a. ap } & \text { ap yedogo }\{\text { ap jedoko }\} \text { Iman many }
\end{array} \\
& \text { b. kwa *kwa yedogo } \\
& \begin{array}{l|l}
\text { c. akomi } & \begin{array}{l}
\text { akomi yedogo }\{\text { akomi jedogo }\} \text { Iwomen many } \\
\text { 'many women' }
\end{array}
\end{array}
\end{aligned}
$$

Reduplication may occur on the concrete nouns like yugum 'stone' to render plurality, yugumyugum 'stones', or en-en for 'pieces of sugarcane'. No inflection appears on mass nouns like $i$ 'water' to express plurality. However, possessive expression is possible as in an $n e-i$ \{I 1swater $\}$ for 'my drink'. This is also true for locative expression, thus: $i-m u$ \{water-LOC $\}$ 'in (the) water/river', e-me \{wood-LOC $\}$ 'in (the) wood/jungle'.

In a noun phrase, nouns precede adjectival words, such as yedok 'large', yedogo 'many' or beq 'small', yields the structure [NP = N Adj]. Thus, $i$ yedogo 'a lot of water' (lit. 'water many') for the alienable nouns, and adian yedogo 'a lot of blood' (lit. 'his-blood many') for the inalienable nouns, illustrated in:

\section{Alienable nouns:}
a. $\quad$ i yedok
b. $\quad$ y yedogo
c. $\quad$ i beq

'flood' (lit. 'water large')

'a lot of water' (lit. 'water many')

'a bit of water' (lit. 'water small') 
Inalienable nouns:

d. adian yedogo 'a lot of blood' (lit. 'his-blood many')

e. adian beq 'a bit of blood' (lit. 'his-blood small')

\section{INALIENABLE NOUNS}

As was outlined in Figure 1 in $\$ 1$, inalienable nouns are divided into four main categories, which are: cultural items discussed in $\$ 4.1$, kinship terms, in $\S 4.2$, body parts, in $\S 4.3$, and experiential events, in $\$ 4.4$.

\subsection{Cultural items}

Wano includes some cultural items as inalienable nouns. They are egin $\{\varnothing$-egin $\} \mid 3 s-b o w \backslash$ 'hisbow' (19) and awi \{ø-awi\} \3s-awi\ 'his-house' (20):

\begin{tabular}{|c|c|}
\hline & \\
\hline & $\begin{array}{l}\text { negin }\{\text { n-ekin }\} \backslash 1 \text { s-bow } \\
\text { 'my bow' }\end{array}$ \\
\hline & $\begin{array}{l}\text { kegin }\{\text { k-ekin }\} \backslash 2 \text { s-bow } \\
\text { 'your.sg-bow' }\end{array}$ \\
\hline & $\begin{array}{l}\text { egin }\{\varnothing \text {-ekin }\} \backslash 3 \text { s-bow } \backslash \\
\text { 'his bow' }\end{array}$ \\
\hline
\end{tabular}

and

$\begin{array}{cl}1 & \begin{array}{l}\text { SINGULAR } \\ \text { nawi }\{\text { n-awi }\} \backslash 1 \text { s-house } \\ \text { 'my house' } \\ \text { kawi }\{\mathrm{k} \text {-awi }\} \backslash 2 \text { s-house }\end{array} \\ 3 & \begin{array}{l}\text { 'your.sg house' } \\ \text { awi }\{\varnothing \text {-awi }\} \backslash 1 \text { s-house } \\ \text { 'his house' }\end{array}\end{array}$

PLURAL

ninyegin $\{$ nin-ekin $\backslash 11 \mathrm{p}$-bow

'our bow'

kinyegin \{kin-ekin\} $\mid 2 \mathrm{p}$-bow $\backslash$

'your.pl bow'

inyegin \{in-ekin\} |3p-bow

'their bow'

PLURAL

ninyawi $\{$ nin-awi $\} \backslash 1 \mathrm{p}$-housel

'our house'

kinyawi \{kin-awi\} 12p-housel

'your.pl house'

inyawi $\{$ in-awi $\} \backslash 3 \mathrm{p}$-housel

'their house'

Syntactic evidence for the distinction between cultural items and body part nouns is shown in (21). In (21a), Wano allows phrases like awi at e-ne 'a house of his', but not *eruk at ene 'hair of his/its' in (18b).

$\begin{array}{llll}\text { a. } & \text { awi } & \text { at } & \text { ene } \\ & \varnothing \text {-awi At } & \phi \text {-ene } \\ \text { 3s-house he } & \text { 3s-belonging } \\ & \text { 'a house of his' } \\ \text { b. } & \text { *eruk at ene } \\ & \varnothing \text {-etuk at } & \text {-ene } \\ \text { 3s-hair he } & \text { 3s-belonging } \\ \text { 'hair of his' }\end{array}$

\subsection{Kinship terms}

All kinship terms are vowel-initial, as listed in (22), but items with initial $u$ are not attested.
a. $\quad \frac{\text { Vowel-final Root }}{\text { SINGULAR }}$
a1. $\quad$ are $\{\varnothing$-ate $\} \backslash 3$ s-uncle $\backslash$
'his/her uncle'
PLURAL
arevi $\{\varnothing$-ate-vi $\} \backslash 3$ s-uncle-PL\}
'his/her uncles' 


\begin{tabular}{|c|c|c|}
\hline a2. & icawo $\{\varnothing$-itja & icawowi $\{\varnothing-\mathrm{it}\}$ \\
\hline & 'his/her aunt' & 'his/her aunts' \\
\hline a3. & omba $\{\varnothing$-ompa $\} \mid 3$ s-grandpa & ombavi $\{\varnothing$-ompa-vi $\} \backslash 3$ p-grandpa-PL $\backslash$ \\
\hline 34 & $\begin{array}{l}\text { 'his/her grandfather' } \\
\text { owe \{ø-owe }\end{array}$ & 'his/her grandfathers' \\
\hline & $\mid 3$ s-older sibling oSS $\mid$ & $\mid 3$ s-older sibling oSS-PL| \\
\hline a5. & $\begin{array}{l}\text { 'his/her older brother/sister' } \\
\text { iri }\{\varnothing \text {-iti }\} \backslash 3 \text { s-sibling oDS } \backslash \\
\text { 'his/her sister/brother' }\end{array}$ & $\begin{array}{l}\text { 'his/her older brothers/sisters' } \\
\text { irivi }\{\varnothing \text {-iti-vi }\} \text { \3s-sibling oDS-PL। } \\
\text { 'his/her sisters/brothers' }\end{array}$ \\
\hline $\mathrm{b}$ & Consonant-final Root & \\
\hline b1. & awot $\{\varnothing$-awot $\}$ & awori $\{\varnothing$-awot-i $\}$ \\
\hline & er sibling oSS $\backslash$ & $\mid 3 s$-younger sibling oSs-PL| \\
\hline b2. & $\begin{array}{l}\text { 'his/her younger brother/sister' } \\
\text { abut }\{\varnothing \text {-abut }\} \backslash 3 \text { s-child.oM } \backslash \\
\text { 'his child' }\end{array}$ & $\begin{array}{l}\text { 'his/her younger brothers/sisters' } \\
\text { aburi }\{\varnothing \text {-abut-i }\} \backslash 3 \text { s-child.oM-PL } \\
\text { 'his children' }\end{array}$ \\
\hline b3. & $\begin{array}{l}\text { ayak }\{\varnothing \text {-ajak }\} \text { |3s-child.oF } \\
\text { 'her child' }\end{array}$ & $\begin{array}{l}\text { acui }\{\varnothing \text {-atjui }\} \backslash 3 \text { s-children.oF } \backslash \\
\text { 'her children' }\end{array}$ \\
\hline
\end{tabular}

In the nuclear family, that includes parents, spouses, children and siblings, I will describe the terms used in the parent-child, spousal and sibling relationship (cf. Foley 1997:133-149).

In the parent-child relationship, the terms for ego's father and mother do not depend on ego's sex - cf. Burung (2017: §5.2, 2018) for discussion on deixis.
SINGULAR
PLURAL
a. ova $\{\varnothing$-ova $\}$ |3s-father|
ovavi $\{\varnothing$-ova-vi $\} \backslash 3$ s-father-PL\}
'his/her father'
'his/her fathers'
b. $\quad$ ica $\{\varnothing$-itja $\} \backslash 3$ s-mother\}
'his/her mother'
icavi $\{\varnothing$-itja-vi $\} \backslash 3$ s-mother-PL\}
'his/her mothers'

When ego is a parent, the term for 'child' is determined by the sex of ego, regardless of the sex of the child. In English, the sex of a child is clear by the terms 'son' and 'daughter'. In Wano, however, the sex of a parent is clear by the terms abut, i.e. 'child of male person', and ayak, i.e. 'child of female person'. (24a) is the term for a child of a male ego, while (24b) is for a female ego - cf. (22b). Note that this also holds for other languages in the Dani language family, as observed by Bromley (1973: 9). He writes, "The kinship terminologies in these languages group a woman's children with a man's children; the terminologies in the Western Dani and Grand Valley areas distinguish them."

\section{a. Male ego forms: 'his child'}

SINGULAR
abut
$\varnothing$-abut
3s-child.oM
'his child'
b. Female ego forms: 'her child'
SINGULAR
ayak
$\varnothing$-ajak
3s-child.oF
'her child'

PLURAL

\section{aburi}

$\emptyset$-abut-i

3s-child.oM-PL

'his children'

PLURAL
acui
$\varnothing$-atjui
3s-children.oF
'her children'


The distribution of (24) is outlined in (25-26). SINGULAR TERMS
abut $\{\varnothing$-abut $\} \mid 3$ s-child.oM $\backslash<3$ s.M $>$ SG 'his child'
ayak $\{\varnothing$-ajak $\} \backslash 3$ s-child.oF $\backslash<3$ s.F $>$ SG 'her child'

\begin{tabular}{|c|c|c|c|}
\hline & & ADDRESSEE & \\
\hline & SPEAKER & Male & Female \\
\hline al. & Father & i. ninyabut & $\begin{array}{l}j . \text { *ninyabut } \\
j j . \text { kayak }\end{array}$ \\
\hline$a 2$. & Mother & $\begin{array}{l}\text { i. *ninyayak } \\
\text { ii. kabut }\end{array}$ & j. ninyayak \\
\hline \multirow[t]{2}{*}{$a 3}$. & Non-parents & $\begin{array}{l}\text { i. kabut } \\
\text { ii. kabut-ayak }\end{array}$ & $\begin{array}{l}\text { j. kayak } \\
\text { jj. kayak-abut }\end{array}$ \\
\hline & SPEAKER & $\begin{array}{l}\text { ADDRESSEE } \\
\text { Spouse (husband-wife) }\end{array}$ & Other \\
\hline$b 1$. & Father & $\begin{array}{l}\text { i. ninyayak-ninyabut } \\
\text { ii. ninyayak-nabut }\end{array}$ & j. ayak-nabut \\
\hline$b 2$. & Mother & $\begin{array}{l}\text { i. ninyabut-ninyayak } \\
\text { ii. ninyabut-nayak }\end{array}$ & j. abut-nayak \\
\hline$b 3$. & Non-parents & $\begin{array}{l}\text { i. kinyabut-kinyayak } \\
\text { ii. kinyayak-kinyabut }\end{array}$ & $\begin{array}{l}\text { j. inyayak-inyabut } \\
\text { jj. inyabut-inyayak }\end{array}$ \\
\hline
\end{tabular}

The plural forms of abut 'his child' and ayak 'her child' in (25) are given in (26).

PLURAL TERMS

aburi $\{\varnothing$-abut-i $\} \backslash 3$ s-child.oM-plural $\backslash 3 \mathrm{~s}$.M $>$ PL 'his children' acui $\{\varnothing$-atjui\} $\mid 3 \mathrm{~s}$-child.oF:plural $\backslash<3$ s.F $>$ PL 'her children'

\begin{tabular}{|c|c|c|c|}
\hline & SPEAKER & $\begin{array}{l}\text { ADDRESSEE } \\
\text { Male }\end{array}$ & Female \\
\hline al. & Father & i. ninyaburi & $\begin{array}{l}j . *_{\text {ninyaburi }} \\
\text { jj. kacui }\end{array}$ \\
\hline$a 2$. & Mother & $\begin{array}{l}\text { i. *ninyacui } \\
\text { ii. kaburi }\end{array}$ & j. ninyacui \\
\hline \multirow[t]{2}{*}{ a3. } & Non-parents & $\begin{array}{l}\text { i. kaburi } \\
\text { ii. kaburi-acui }\end{array}$ & $\begin{array}{l}\text { j. kacui } \\
\text { jj. kacui-aburi }\end{array}$ \\
\hline & SPEAKER & $\begin{array}{l}\text { ADDRESSEE } \\
\text { Spouse (husband-wife) }\end{array}$ & Other \\
\hline bl. & Father & $\begin{array}{l}\text { i. ninyacui-ninyaburi } \\
\text { ii. ninyacui-naburi }\end{array}$ & j. acui-naburi \\
\hline$b 2$. & Mother & $\begin{array}{l}\text { i. ninyaburi-ninyacui } \\
\text { ii. ninyaburi-nacui }\end{array}$ & j. aburi-nacui \\
\hline b3. & Non-parents & $\begin{array}{l}\text { i. kinyaburi-kinyacui } \\
\text { ii. kinyacui-kinyaburi }\end{array}$ & $\begin{array}{l}\text { j. inyacui-inyaburi } \\
\text { jj. inyaburi-inyacui }\end{array}$ \\
\hline
\end{tabular}

The use and implication of abut 'his child' and ayak 'her child' with their plural forms outlined in (25-26) above are explained in \$4.2.1. I will limit the discussion to those kin terms which are common in use, i.e. ninyabut 'our child' (25a.1i) in \$4.2.2, ninyayak 'our child' (25a.2j) in $\$ 4.2 .3$, ninyayak-ninyabut 'our child' (25b.1i) in $\$ 4.2 .4$, and ninyabut-ninyayak 'our child' (25b.2i) in $\S 4.2 .5$, including their plural counterparts in each related section: ninyaburi (23a.1i), ninyacui 
(26a.2j), ninyacui-ninyaburi (26b.1i), and ninyaburi-ninyacui (26b.2i). At a glance, it is not always easy to catch the meaning of each given compounded term. Wano has the following guidelines in (27), for the examples we will be examining, particularly those given in $\$ 4.2 .4$ and $\S 4.2 .5$.
a. The initial term points to the addressee, as in: ninyayak-ninyabut "our child.of.female_our child.of.male", the addressee is a female person, i.e. a mother, and the speaker is a male person, i.e. a father.
b. In a compounding form, the singularised possessor prefix signifies that he/she is the genetic parent of the child. Thus in kayak-ninyabut 'your.sg child.of.female_our child.of.male', the genetic parent is the mother.
c. The fronted term also indicates the focus/centre of the conversation. In those two examples above, the mother is the focus/centre.

By genetic parents in (27b), I mean the true biological father/mother of the child, since Wano culture allows men and women to view the offsprings of their siblings or kin-related persons as their own children. The distinction of who the genetic parents are, as opposed to the non-genetic or adopted parents, is therefore made clear through the language, which in this case is through inalienable nouns. Since the upcoming discussion is limited to the most common used kin terms, the rest of the kin terms found in (25-26) are listed in Appendix 2 including their short description. Further, the meaning of abut is 'his child.of.male', and ayak is 'her child.of.female'. Note the semantic interpretation of both terms, i.e. 'his child' and 'her child' refer to the possessors (male/female possessors), while 'of.male' and 'of.female' refer to the possessees (abut and ayak). For the sake of practicality and simplicity, unless further clarification is needed, I will here translate abut as 'his child', ayak as 'her child', aburi 'his children', and acui 'her children'. The sex distinction of the possessors will still be indicated on the morphophonological representation. In the following discussion, the semantic interpretation of each term is presented as given in:

\section{Paradigm 1}

\begin{tabular}{|c|c|}
\hline $\begin{array}{r}\text { kin terms } \\
\text { morphophonological structure } \\
\text { morphophonological meaning } \\
\text { semantic interpretation } \\
\text { semantic reading } \\
\text { free translation }\end{array}$ & $\begin{array}{l}\text { abut } \\
\{\varnothing \text {-abut }\} \\
\text { |3s-child.oM } \\
<3 \text { s.M }>\text { SG } \\
\text { "his child.of.male" } \\
\text { 'his child' } \\
\text { aburi } \\
\{\varnothing \text {-abut-i }\} \\
\text { |3s-children.oM } \\
<3 \text { s.M }>\text { PL } \\
\text { "his children.of.male" } \\
\text { 'his children' } \\
\text { inyabut } \\
\text { \{in-abut }\} \\
\text { |3p-child.oM } \backslash \\
<3 \text { p.M }>\text { SG } \\
\text { "their child.of.male" } \\
\text { 'their child' }\end{array}$ \\
\hline
\end{tabular}

\section{FEMALE POSSESSOR}

ayak

$\{\varnothing$-ajak $\}$

$|3 s-c h i l d . o F|$

$<3 \mathrm{~s} . \mathrm{F}>\mathrm{SG}$

"her child.of.female"

'her child'

acui

$\{\varnothing$-atjui $\}$

|3s-children.oF|

$<3$ s.F $>$ PL

"her children.of.female"

'her children'

inyayak

\{in-ajak\}

$\mid 3 p$-child.oF|

$<3$ p.F $>$ SG

"their child.of.female"

'their child' 


\author{
inyaburi \\ \{in-abut-i \\ $\mid 3$ p-children.oM $\mid$ \\ $<3$ p.M $>$ PL \\ "their children.of.male" \\ 'their children'
}

\author{
inyacui \\ \{in-atjui\} \\ |3p-children.of.male। \\ $<3$ p.F $>$ PL \\ "their children.of.female" \\ 'their children'
}

In Paradigm 1, the semantic reading (SR) must be (SR.i) "child.of.singular.male" for the term abut and "child.of.singular.female" for the term ayak, and must not be (SR.ii) *"singular.male.child" for $\boldsymbol{a b u t}$ and *"singular.female.child" for ayak, for the following reasons:

(i) The terms, i.e. abut and ayak, refer to the sex of the possessor, instead of to the sex of the possessee, i.e. the child, as was stated early in this section '... the term for 'child' is determined by the sex of ego, regardless of the sex of the child.' Thus, in this case, (ii) (SR.i) indicates that abut refers to a child who belongs to a male possessor, and ayak refers to a child who belongs to a female possessor. Or in terms of inalienability, abut inalienably includes a male possessor while ayak inalienably includes a female possessor. On the other hand, (SR.ii) indicates that $a b u t$ refers to a male singular child, and ayak refers to a female singular child, ruling out the inclusion of the possessor in each term. In (SR.i), the terms refer to the sex of the possessor, while in (SR.ii), the terms refer to the sex of the child. It follows that, (iii) the grammatical structure of $(S R . i)$ 's expression is $\{\{$ child $\}$ of.singular.male $\}$, while the grammatical structure of (SR.ii)'s expression is \{singular.male.child\}, i.e. 'son' in English, and (iv) the semantic interpretation $(S I)$ is then $\langle 3 \mathrm{~s} . \mathrm{M}>\mathrm{SG}$, where $<3 \mathrm{~s} . \mathrm{M}>$ refers to "of.singular.male" and SG, outside the angle brackets, indicates the number of the term, which is singular in this example for abut and ayak - cf. aburi, the semantic interpretation is $<3 \mathrm{s.M}>$ PL, i.e. $\{$ children $\}$ of.singular.male $\}$, and therefore (v) in Wano, (SR.i) is true for the meaning of abut and ayak, and (SR.ii) is not true for the meaning of abut and ayak. Since in (SR.i), abut is 'child.of.male' and ayak is 'child.of.female', whereas in (SR.ii), abut is 'his/her son' and ayak is 'his/her daughter', which is not true in Wano.

For the compound terms, we have, for instance:

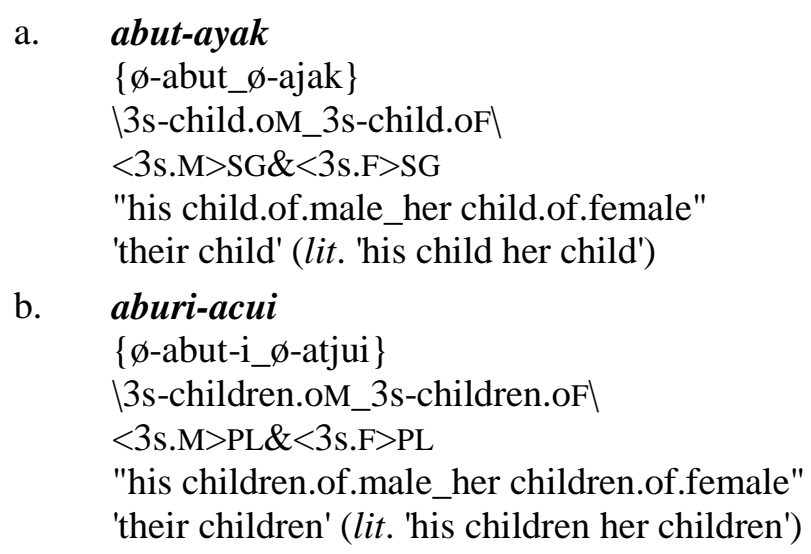

\subsubsection{Abut 'his child' and ayak 'her child'}

As was outlined in Paradigm 1, the term abut 'his child'/"his child.of.male" and ayak 'her child'/"her child.of.female', cf. (25), with their plural forms aburi 'his children'/"his children.of.male' and acui 'her children'/"her children.of.female', cf. (26), are semantically 
exclusive, i.e. they are strictly male-terms and female-terms. Thus, the terms abut 'his child' and aburi 'his children' are applicable only to male possessor(s). Likewise, the terms ayak 'her child' and acui 'her children' are used only for female possessor(s). When a person, regardless of sex of the person, talks to a male parent, i.e. a father, concerning a child of his and his wife, the $<2$ s.M $>$ SG\&<3s.F>SG term: kabut-ayak (25a.3ii) is used, as given in (29). Consider the semantic interpretation with its literal and free translations.

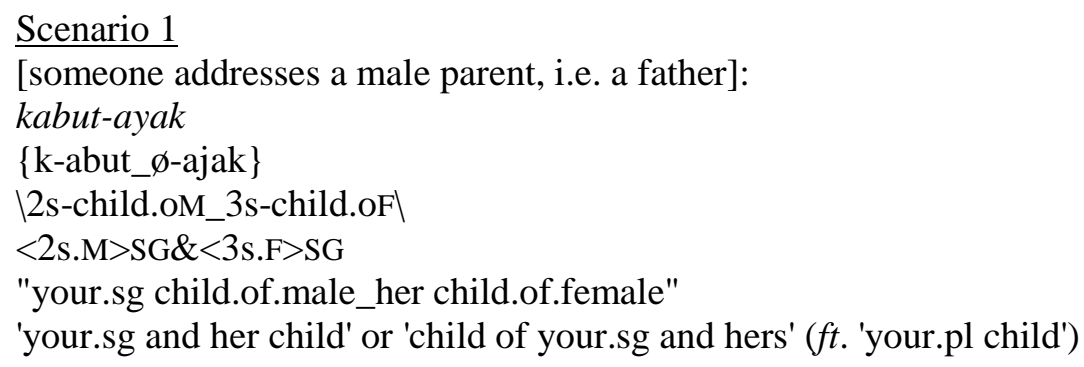

On the other hand, when the person talks to a female parent, i.e. a mother, concerning a child of hers and her husband's, <2s.F>SG\&3s.M>SG term: kayak-abut (25a.3jj) is used, as given in:

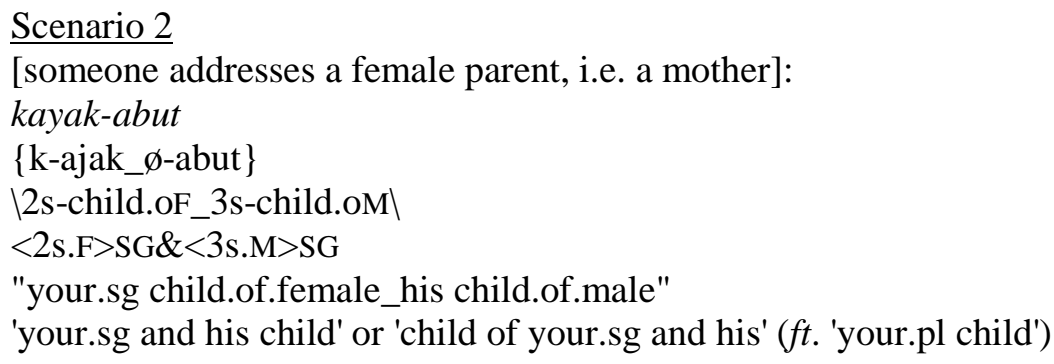

Furthermore, when the person talks to both parents referring to their child, he/she uses either $<2$ p.M $>$ SG\&<2p.F>SG term: kinyabut-kinyayak, or $<2 \mathrm{p} . \mathrm{F}>\mathrm{SG} \&<2 \mathrm{p} . \mathrm{M}>\mathrm{SG}$ term: kinyayakkinyabut for the expression of 'both your.pl child' or 'child of both yours.pl'. The reverse $<3$ s.F $>$ SG $\&<3$ s.M $>$ SG term: ayak-abut and <3s.M $>$ SG $\&<3$ s.F $>$ SG term: abut-ayak signifies possessor-focus in terms of speaker's personal judgement, which is indicated by initial word, cf. (27c). This is illustrated as follows. In (31a), the focus/centre is the father, since abut 'his child' is front-positioned, while in (31b), it is the mother, for ayak 'her child' is front-positioned.

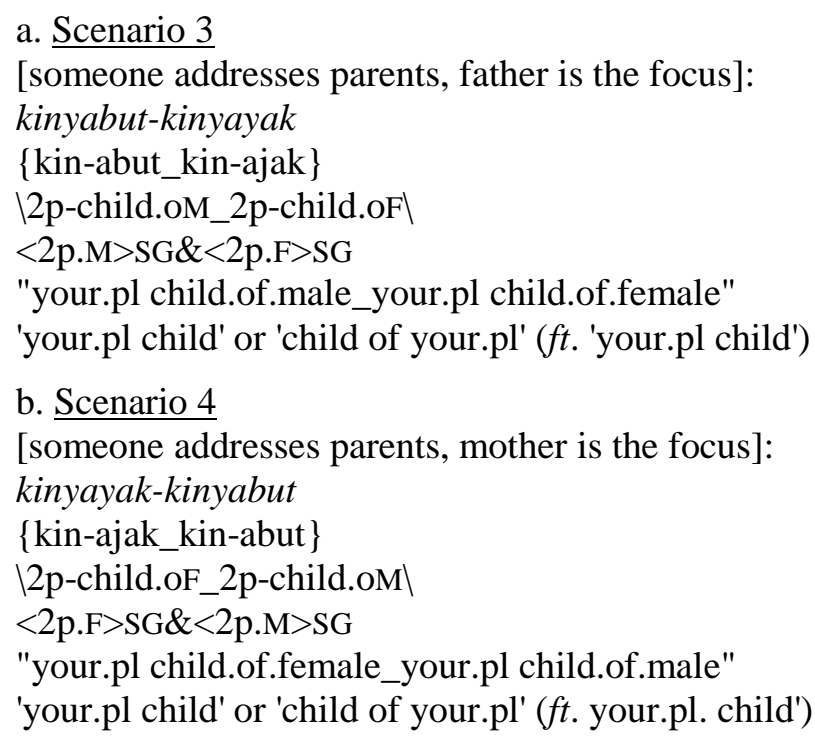


\{k-abut $\mid 2 \mathrm{~s}$-child.oM $\backslash<2 \mathrm{~s} . \mathrm{M}>\mathrm{SG}$ 'your.sg child', see (25a.2ii). This term can be used by other speaker(s), regardless of sex distinction, when talking to a man about his child (25a.3i).

\subsubsection{Ninyayak-ninyabut 'our child'}

This is restricted to genetic parents. The compound term ninyayak-ninyabut \{nin-ajak_ninabut\} \1p-child.oF_1p-child.oM $\quad<1 \mathrm{p} . \mathrm{F}>\mathrm{SG} \&<1 \mathrm{p} . \mathrm{M}>\mathrm{SG} \quad$ "our child.of.plural.female_our child.of.plural.male", which is: 'our child' (25b.1i), uttered in the context of husband-wife relationship by the husband. Recall the guidelines in (27), how do we know that the father is the speaker? The fronted term is the clue. In the case of ninyayak-ninyabut 'our child', it is ayak 'her-child', that is fronted to indicate that the mother is the addressee and that the mother is the focus. Both father and mother are genetic parents. This term is the pair of the one given in (36). The plural form is ninyacui-ninyaburi \{nin-atjui_nin-abut-i\} $\backslash 1 \mathrm{p}$-children.oF_1p-child.oM-PL 1 $<1$ p.F>PL\&<1p.M>PL"our children.of.plural.female_our children.of.plural male", which is: 'our children' (25b.1i).

$\underline{\text { Scenario } 5}$ (25b.1i) and (26b.1i) - cf. (37)

[a husband addresses his wife]:

a. ninyayak-ninyabut

\{nin-ajak_nin-abut $\}$

$\backslash 1 \mathrm{p}$-child.oF_1p-child.oM $\backslash$

$<1$ p.F $>$ SG\&<1p.M>SG

"our child.of.plural.female_our child.of.plural.male"

'our child'

b. ninyacui-ninyaburi

\{nin-atjui_nin-abut-i $\}$

$\backslash 1 \mathrm{p}$-children.oF.PL_1p-child-PL

$<1$ p.F $>$ PL\& $<1$ p.M $>$ PL

"our children.of.plural.female_our children.of.plural.male"

'our children'

Both compounded kin terms in (34) are used only for/by genetic parents. When the husband wants to single out one of the parents as the genetic parent, the terms kayak-ninyabut, i.e. $<2$ s.F $>$ SG\& $<1$ p.M $>$ SG (35a) or ninyayak-nabut, i.e. $<1$ p.F $>$ SG $\&<1 \mathrm{~s} . \mathrm{M}>\mathrm{SG}(35 \mathrm{~b})$ is used. Note in (35a), the female term in the singular form, i.e. kayak 'your.sg child' or $\langle 2 \mathrm{~s} . \mathrm{F}\rangle \mathrm{SG}$, indicates that the genetic parent is the mother - cf. (30b). On the other hand, in (35b), the male term is in the singular form, i.e. nabut 'my child' or $<1 \mathrm{s.M}>\mathrm{SG}$, thus marks the father as the genetic parent.

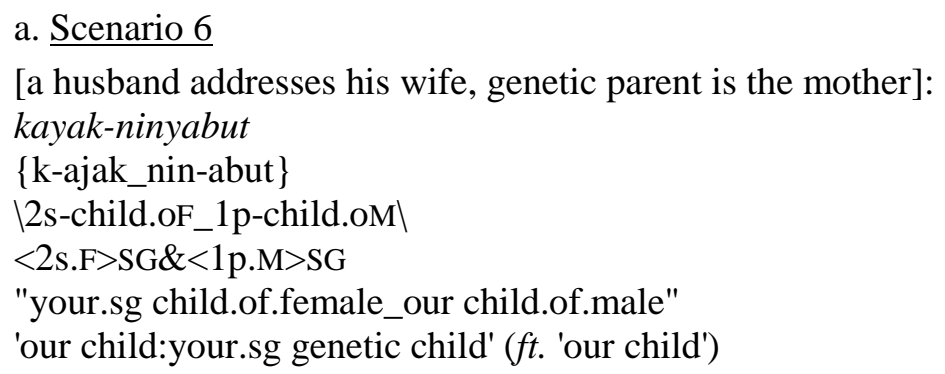




\title{
b. Scenario 7
}

[a husband addresses his wife, genetic parent is the father]:

ninyayak-nabut

\{nin-ajak_n-abut

$\backslash 1$ p-child.oF_1s-child.oM $\backslash$

$<1$ p.F $>$ SG\&<1s.M $>$ SG

"our child.of.female_my child.of.male"

'our child:my genetic child' (ft. 'our child')

The plural forms for (35a) is kacui-ninyaburi, i.e. $<2 \mathrm{~s} . \mathrm{F}>\mathrm{PL} \&<1 \mathrm{p} . \mathrm{M}>\mathrm{PL}$ and for $(35 \mathrm{~b})$ is ninyacui-naburi, i.e. $<1$ p.F $>$ PL $\&<1$ s.M $>$ PL. The examples in (35) are symmetric to those given in (37).

\subsubsection{Ninyabut-ninyayak 'our child'}

The compound term ninyabut-ninyayak, \{nin-abut_nin-ajak\} 11p-child.oM_1p-child.oF $<1$ p.M $>$ SG\&<1p.F>SG 'our child' (36a cf. 25b.2i), is used by the wife in the context of husbandwife relationship. Both husband and wife are genetic parents. The father is the focus since $a b u t$ 'his child' is fronted. The plural form of ninyabut-ninyayak 'our child' is ninyaburi-ninyacui \{nin-abut-i_nin-acui\} $\backslash 1 \mathrm{p}$-child.oM-PL_1p-children.oF $\langle$ 1p.M $>$ PL $\&<1 \mathrm{p}$.F $>$ PL 'our children' (36b cf. 26b.2i).

Scenario 8 (25b.2i) and (26b.2i) - cf. (34)

[a wife addresses her husband]:

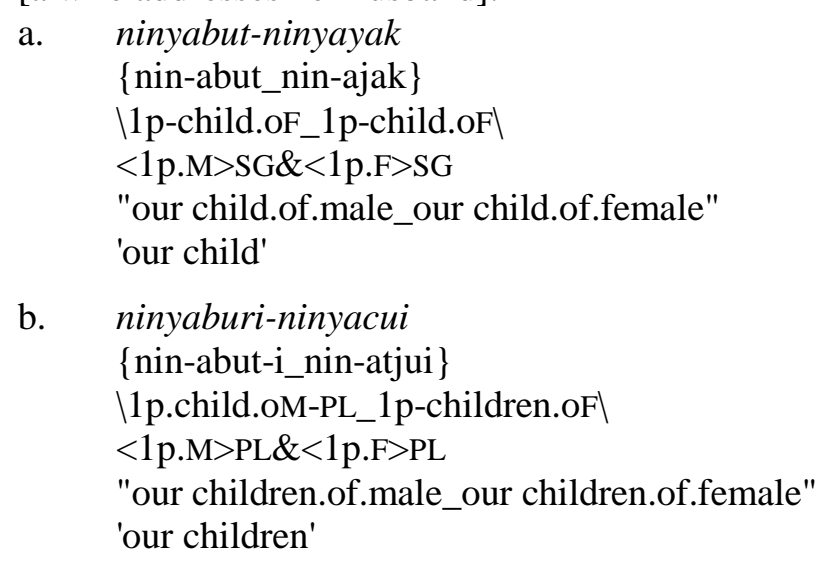

When the wife wants to specify either one of the parents as the genetic parent, the terms kabutninyayak, i.e. $<2$ s.M $>$ SG\& $<1$ p.F $>$ SG (37a) or ninyabut-nayak, i.e. $<1 \mathrm{p} . \mathrm{M}>\mathrm{SG} \&<1$ s.F $>$ SG (37b) is used.

\author{
a. $\underline{\text { Scenario } 9}$ \\ [a wife addresses her husband, genetic parent is the father]: \\ kabut-ninyayak \\ \{k-abut_nin-ajak $\}$ \\ |2s-child.oM_1p-child.oF.PLl \\ $<2$ s.M $>$ SG\& $<1$ p.F $>$ SG \\ "your.sg:genetic child.of.male_our child.of.female" \\ 'our child'
}




\section{b. Scenario 10}

[a wife addresses her husband, genetic parent is the mother]:

ninyabut-nayak

\{nin-abut_n-ayak\}

$\backslash 1$ p-child.oM_1s-child.oF $\backslash$

$<1$ p.M $>$ SG \& $<1$ s.F $>$ SG

"our child.of.male_my:genetic child.of.female"

'our child'

The plural forms of (37a) is kaburi-ninyacui, i.e. $<2$ s.M $>$ PL $\&<1 \mathrm{p} . \mathrm{F}>\mathrm{PL}$ and of $(37 \mathrm{~b})$ is ninyaburi-nacui, i.e. $<1$ p.M $>$ PL $\&<1$ s.F $>$ PL. The examples in (37) are symmetric to those in (35).

When the sex of the child has to be specified, ap 'man' or kwa 'woman' modifies the head noun, although this is not a very common practice.

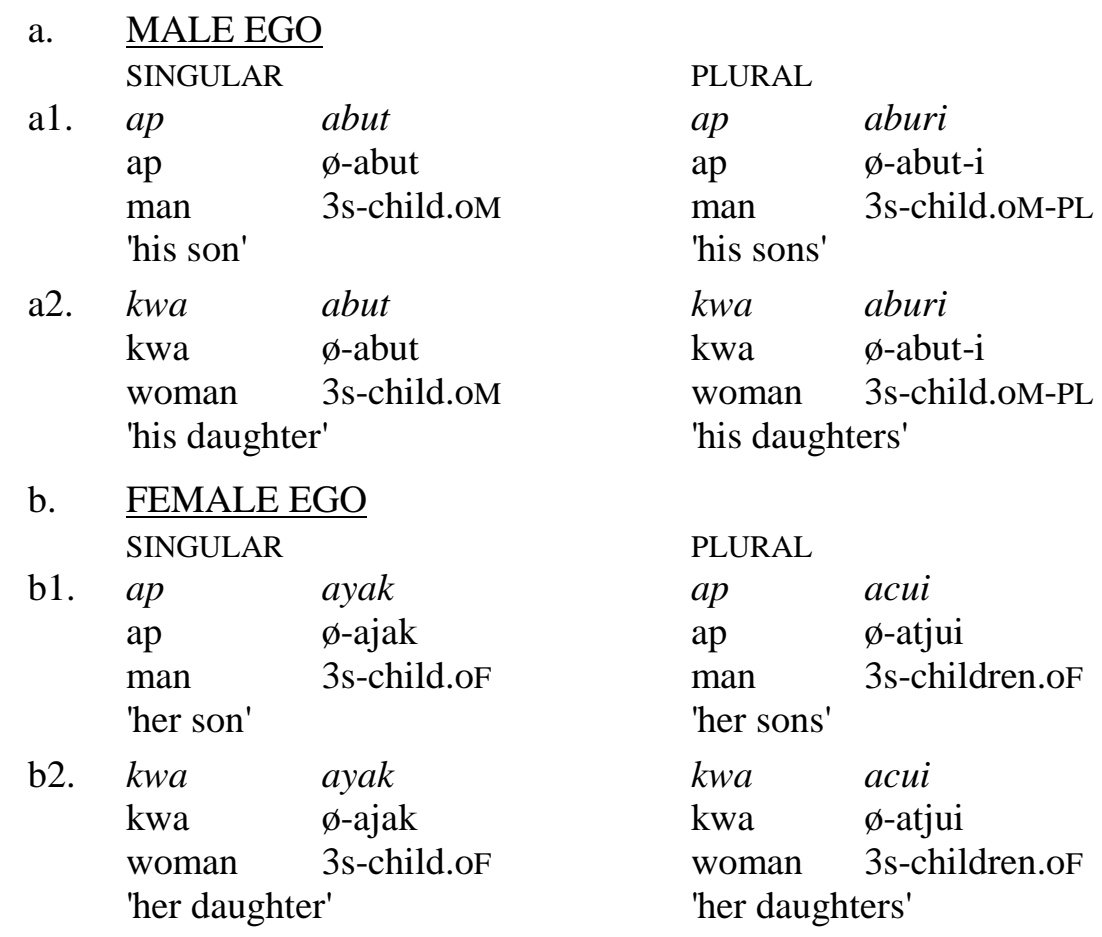

Further mention must be made regarding abut 'his child' and ayak 'her child'. Such terms refer to the kinship relation, while the generic term for 'child' as opposed to grown-ups or adults is expressed by a verbal phrase nonggobe 'child', that is a figurative speech of nong \{non-\} 'consume' $+k\{\mathrm{k}-\}$ 'REAL' $+o\{-\mathrm{o}\}$ '3s.SBJ' + be $\{\mathrm{be}\}$ 'small'; literally: 'little one who eats', implies 'the one who still needs to be fed'. This term is used for infants, toddlers and young children. Its plural form is derived by means of reduplication and suffixed with vi \{-vi\} 'PL', rendering nonggodunggwi 'children'; nong \{non- $\}$ 'consume' $+k\{\mathrm{k}-\}$ 'REAL' $+o\{-\mathrm{o}\}$ '3s.SBJ' dung \{dun- $\}$ 'REDUP' $+g\{\mathrm{k}-\}$ 'REAL' $+v i\{$-vi $\}$ 'plural'.

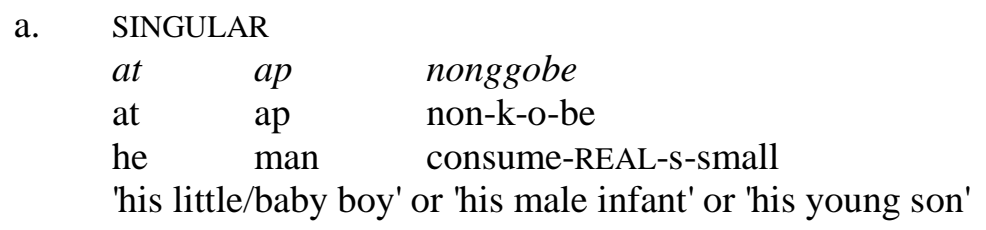


b. PLURAL

$\begin{array}{lll}\text { at } & k w a & \text { Nonggodunggwi } \\ \text { at } & \text { kwa } & \text { non-k-o d-un-k-vi } \\ \text { he } & \text { woman } & \text { consume-REAL-s-small REDUP-PL } \\ \text { 'his little/baby girls' or 'his female infants' or 'his young daughter' }\end{array}$

Regarding spousal relationship, different terms are used for spouses.
SINGULAR
PLURAL
a. agwe $\{\varnothing$-akwe $\}|3 \mathrm{~s}-w i f e|$
agwevi $\{\varnothing$-akwe-vi $\} \mid 3 \mathrm{~s}$-wife-PL।
'his wife'
'his wives'
b. $\quad$ oiny $\{\varnothing$-oin $\} \backslash 3$ s-husband $\backslash$
oinyi $\{\varnothing$-oin-i $\} \backslash 3$ s-husband-PL\}
'her husband'
'her husbands'

Pertaining to (40), Wano expresses something like 'family' or 'household' in terms of sex distinction of the possessor as illustrated in (41a), for 'family of male', and (41b), for 'family of female'.

\author{
a. MALE EGO \\ agwebut $\{\varnothing$-akwe_ø-but\} $\mid 3$ s-wife_3s-child.oM\} \\ 'his family/household' \\ b. FEMALE EGO \\ oinyayak $\{\varnothing$-oin_ $\varnothing$-ajak\} $\backslash 3$ s-husband_3s-child.oF\ \\ 'her family/household'
}

Concerning sibling relationship, in the ego's own generation, when ego and sibling are of the same sex (oSS), age determines the choice of referring terms - see Burung (2017: §5.2; forthcoming) for discussion on deixis.
a. $\quad$ awot $\{\varnothing$-awot $\} \backslash 3$ s-younger sibling.oss $\backslash$
"his/her younger sibling of.same.sex"
'his younger brother' or 'her younger sister' (lit. 'his/her younger
sibling.of.same.sex')
b. awori $\{\varnothing$-awot-i $\} \mid 3 s$-younger sibling.oSS-PL।
"his/her younger siblings of.same.sex"
'his younger brothers' or 'her younger sisters' (lit. 'his/her younger
siblings.of.same.sex)
c. owe $\{\varnothing$-owe $\}$ |3s-older sibling.oss \}
"his/her older sibling.of.same.sex"
'his older brother' or 'her older sister'
d. owewi $\{\varnothing$-owe-wi\} $\mid 3$ s-older sibling.oss-PL।
"his/her older siblings.of.same.sex"
'his older brothers' or 'her older sisters'

If ego and sibling are of the different sexes (oDS), a different term is used regardless of age distinction.

\author{
SINGULAR \\ a. $\quad$ iri $\{\varnothing$-iti $\}$ 3s-sibling.oDS $\backslash$ \\ "his/her sibling.of.different.sex" \\ 'his sister/her brother' (lit. 'his/her sibling.of.different.sex')
}


PLURAL

b. $\quad$ irivi $\{\varnothing$-iti-vi $\} \mid 3$ s-sibling.oDS-PL $\mid$

"his/her siblings.of.different.sex"

'his sisters/her brothers' (lit. 'his/her siblings.of.different.sex')

\subsection{Body parts}

Nouns denoting body parts are divided into two categories, namely: solid (\$4.3.1) and liquid (§4.3.2) body parts.

\subsubsection{Solid bodily parts}

Items referring to body parts including hand, hair, eyes, head, and the like, are categorised as solid body parts. Examples in (44) give only third person-singular possessor.
a. $\quad$ indit $\{\varnothing$-intit $\} \backslash 3 \mathrm{~s}$-cheek 'his cheek'
b. enak $\{\varnothing$-enak $\} \backslash 3$ s-tooth $\backslash$ 'his tooth'
c. $\quad a k w i\{\varnothing$-atkwi $\} \backslash 3$ s-nosel 'his nose'
d. ombagit $\{\varnothing$-ompakit $\} \backslash 3 \mathrm{~s}$-vein\'his vein'

\subsubsection{Liquid bodily parts}

Items referring to bodily excreta including tears, saliva, blood, and the like, are in the liquid body parts group. Terms for excretive items are all $a$-initial, but can be realised without the initial vowel, with some exceptions. The term owarid 'his saliva' takes the vowel $o$ \{o- $\}$ instead of $a\{\mathrm{a}-\}$. Likewise, eravun 'her menstrual flow' is $e$-initial. The possessor of term enan 'excrement' is zero, $\{\varnothing-\}$. Excretions, once they have been detached from the body are no longer possessed and the possessive marker will be dropped. Examples are given in:
a. ATTACHED TO BODY
b. DETACHED FROM BODY
ademburu
a-de-mputu
demburu
3s-cry-liquid
'his tears'
de-mputu
cry-liquid
'tears'

The list of liquid bodily excretive items follows:

\begin{tabular}{|c|c|c|c|}
\hline \multicolumn{2}{|c|}{ a. ATTACHED TO BODY } & \multicolumn{2}{|c|}{ b. DETACHED FROM BODY } \\
\hline ademburu & 'his tears' & demburu & 'tears' \\
\hline adian & 'his blood' & dian & 'blood' \\
\hline ameiyo & 'his urine' & meiyo & 'urine' \\
\hline amburu & 'his liquid' & mburu & 'liquid' \\
\hline angguret & 'his mucus' & ngguret & 'mucus' \\
\hline anggudit & 'his pus' & kundit & 'pus' \\
\hline aringgu & 'his snot' & tinggu & 'snot' \\
\hline enggodan & 'his sperm' & yenggodan & 'sperm' \\
\hline avun & 'her menstrual flow' & tavun & 'menstrual flow' \\
\hline owarid & 'his saliva' & warid & 'saliva' \\
\hline
\end{tabular}

Notice that ademburu is an inflection of a-de-mburu '3s-cry-liquid', and ayenggodan is probably of ø-aye-nggodan '3s-penis-?'. 


\subsection{Experiential events}

Terms denoting experiential events are divided into two categories: nouns related to the cognitive sphere and those to do with physiological sense or feeling. A detailed discussion of experiential events is given in chapters $7 \S 7.2$ and $9 \$ 9.4$ (see also Burung 2002, 2003, 2004). A brief account is given here.

Words related to thought, memory, dream and the like fall under the cognition type of experiential events. The word enokweid \{ $\varnothing$-enokweid\} $\mid 3 \mathrm{~s}$-mind $\backslash$ in (47) is an example, which can be translated as 'his thought', or 'his mind', or 'his idea'.

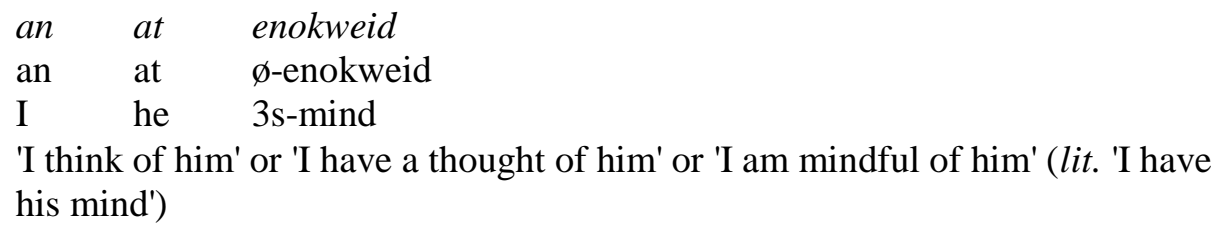

Words related to physical feeling and emotion, like happiness, heaviness or pain, are properties of the physiological domain of experiential events. The word anggin \{ $\varnothing$-ankin\} |3s-weariness। in (48) is an example that can be translated as 'his weariness', or 'his tiredness', and the like.

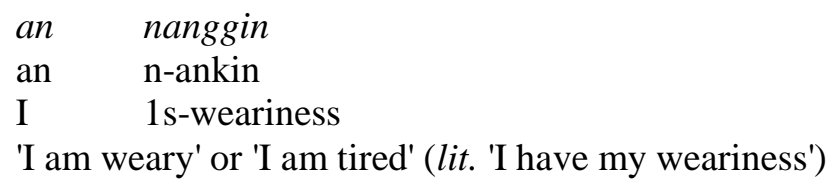

\section{INALIENABLY MARKED WORDS}

Lexical items expressing beneficiary ( $\$ 5.1)$, and comitative-abessive (§5.2) are also inalienably marked.

\subsection{Benefactive}

The word ambit \{ø-ampit\} 13s-sakel 'his sake' marks 'beneficiary', which takes direct object/possessor prefixes. In an everyday mother and child's dialogue we will notice the use of ambit 'his sake' for third person singular in (49c, d). In (49e), for first person singular, and (49f) for second person singular. What follows is an example of a conversation (Burung's fieldnote, Biricare 1994) where a mother was about to go to the field for some cassava leaves to feed her pig. Having been noticed by her child, she was called to - hence the conversation in (49), follows:

$$
\begin{aligned}
& \text { a. Child: } \\
& \text { nica-o, ngga nendik-a. } \\
& \text { n-itja }=0 \quad \text { nka n-ent-ik=a } \\
& \text { 1s-mother=PAUS where go-2s-PROG=Q } \\
& \text { 'My mother, where are you going?' }
\end{aligned}
$$

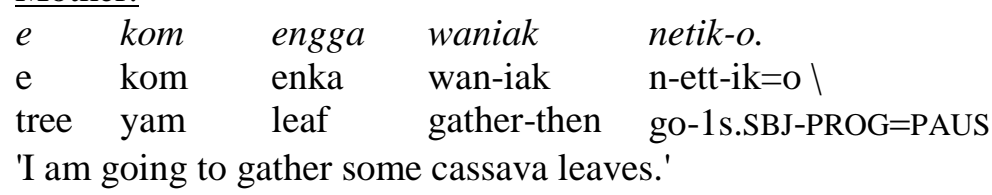


c. Child:

ta Ne ambit-a.

ta $\quad \mathrm{Ne} \quad \varnothing$-ampit=a

SPEC S.REF 3s-sake-Q

'for whom?' (lit. 'for whose sake?')

d. Mother:

nanggwom ambit-o.

n-awom $\quad \varnothing$-ampit=o $\backslash$

2s-pig 3s-sake-PAUS

'for my pig.'

e. Child:

$\begin{array}{lll}\text { nambit } & \text { ta, } & \text { nano- } a \text {. } \\ \text { n-ampit } & \text { ta } \mid & \text { nano=a } \\ \text { 1s-sake } & \text { SPEC } & \text { what }=\mathrm{Q}\end{array}$

'What is for me?' (lit. 'What is for my sake?')

f. Mother:

\begin{tabular}{|c|c|c|c|c|c|c|}
\hline $\begin{array}{l}\text { nda } \\
\text { nta } \\
\text { here }\end{array}$ & $\begin{array}{l}\text { doiak } \\
\text { do-iak } \\
\text { stay-DSEQ }\end{array}$ & $\begin{array}{l}t a, \\
\text { ta } \mid \\
\text { SPEC }\end{array}$ & $\begin{array}{l}\text { bok-o, } \\
\text { bok=0 | } \\
\text { good= SPEC }\end{array}$ & $\begin{array}{l}\text { nggwen } \\
\text { nkwen } \\
\text { earth }\end{array}$ & $\begin{array}{l}\text { kuma } \\
\text { kuma } \\
\text { peanut }\end{array}$ & $\begin{array}{l}\text { ne } \\
\text { ne } \\
\text { SREF }\end{array}$ \\
\hline $\begin{array}{l}\text { kambit } \\
\text { k-ampit } \\
\text { 2s-sake }\end{array}$ & $\begin{array}{l}\text { wiriak } \\
\text { wit-iak } \\
\text { pull ou }\end{array}$ & & \begin{tabular}{l} 
tetik- $O$. \\
t-ett-ik=o \} $\\
{\text { intend-1s.SB }}$ & $\mathrm{G}=$ & & \\
\hline
\end{tabular}
\end{tabular}

[Burung's fieldnotes, Biricare 1994]

\subsection{Comitative-Abessive}

There are five postpositions that have a basic comitative-abessive meaning. They are inyom \{ $\varnothing-$ with\} I3s-with\ 'his with', ambek 'his without', adik 'his aloneness', and imbirak 'his togetherness'. The antonyms, inyom and ambek occur following (pro)nouns, with which they agree in person/number. While inyom occurs in the coordinate structure of [(NP (inyom)) NP inyom], ambek strictly has [(NP) NP ambek]. Further discussion is given in chapter 8 §8.2.2.
a. an
$\begin{array}{ll}\text { (ninyom) } & \text { kat } \\ \text { n-inom } & \text { Kat }\end{array}$
kinyom
werak-o.
an n-inom Kat k-inom
we-et-ak=o $\backslash$
I 1s-with you.sg
2s-with
come-1s.SBJ-then= PAUS
'I came with you.sg'
a'. an ninyom kat
an n-inom Kat
(kinyom) wendak-o.
I 1s-with you.sg 2s-with
we-ent-ak=o $\backslash$
'You.sg came with me.'
b. an kat
kat
kambek
an kat
k-ampek
I you.sg 2s-without
'I came without you.sg'
werak-o.
we-et-ak=ol
b'. an kat
an kat
nambek
n-ampek
1s-without
'You.sg came without me.'
come-1s.SBJ-then=PAUS
wendak-o.
we-ent-ak=o $\backslash$
come-2s.SBJ-then=PAUS 
While it is possible to employ the comitative inyom '3s-with' twice as in (50a) and (50a') or only once as in (51a), the abessive ambek 'without' can only occur once as in (50b) and (50b'). Something like (51b), intended as expressing a correlative conjuction: 'neither I, nor you' is not possible.

$\begin{array}{llllll}\text { a. } & \text { an } \quad \text { kat } & \text { kinyom } & \text { werak-o. } & \\ \text { an } \quad \text { kat } & \text { k-inom } & \text { w-et-ak=ol } \\ \text { I } & \text { you.sg } & \text { 2s-with } & \text { come-1p.SBJ-D.SEQ=PAUS } \\ \text { 'I came with you.sg' } & & & \\ \text { b. } & \text { *an } & \text { nambek } & \text { kat } & \text { kambek } & \text { werak-o. } \\ \text { an } & \text { n-ambek } & \text { kat } & \text { k-ambek } & \text { w-et-ak=ol } \\ \text { I } & \text { 1s-without } & \text { you.sg } & \text { 2s-without } & \text { come-1p.SBJ-D.SEQ=PAUS }\end{array}$

Some further examples. A conversation narrated in (52) took place in Iratoi some time in 1992. It was when I was asking some young men about the murder of an old woman who was accused as being the cause of my first language teacher's death. Note in (52a), Speaker 1 was interrupted by Speaker 2, in (52b), when he was informing me about the killer. He then responded in (52c), which was followed by another conversant with his additional remark on the murderer in (52c').

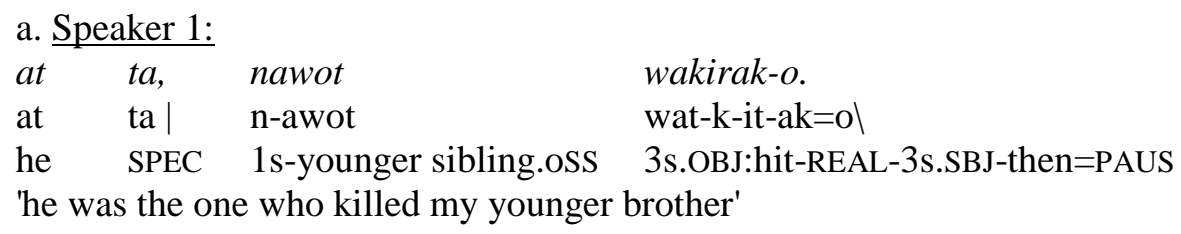

The comitative imbirak '3s-together' has no paired antonym.

$$
\begin{array}{lllll}
\text { nit } & \text { apik } & \text { ninyimbirak, } & \text { yanduk } & \text { iruid-o. } \\
\text { nit } & \text { apik } & \text { nin-impitak } \mid & \text { janduk } & \text { it-uid=o } \backslash \\
\text { we } & \text { all } & \text { 3p-togetherness } & \text { bridge } & \text { do-1p.SBJ:INCEP=PAUS }
\end{array}
$$

'we all together, let us make a bridge!' or 'let us all make the bridge together!' 
Wano, however, can make use of the negator adik '3s-aloneness' or '3s-nothing' to express the opposite of imbirak '3s-togetherness'.

$$
\begin{aligned}
& \text { nit apik niny-adik, } \quad \text { yanduk } \quad \text { iruid-o. } \\
& \text { nit apik nin-adik } \quad \text { janduk it-uid=o } \backslash \\
& \text { we all } 1 \text { p-aloneness bridge do-1p.SBJ:INCEP=PAUS } \\
& \text { 'we alone, let us make a bridge!' or 'let us all make a bridge by ourselves!' or 'let } \\
& \text { us all make a bridge with no help!' }
\end{aligned}
$$

In comparison, while adik '3s-aloneness' simply expresses the opposite sense of imbirak '3stogetherness', ambek '3s-without' may be used to refer to one's right to do something.

$$
\begin{aligned}
& \text { a. At anggwom ambek wakirak-o. } \\
& \text { At a-wom } \varnothing \text {-ampek wat-k-it-ak=o \} } \\
{\mathrm{He} \text { 3s-pig 3s-without 3s.OBJ:hit-REAL-3s.SBJ-then=PAUS }} \\
{\text { 'he himself killed his pig' (because of ownership right/privilege) }} \\
{\text { b. At anggwom Adik wakirak-o. }} \\
{\text { At a-wom } \varnothing \text {-adik } \quad \text { wat-k-it-ak=o } \backslash} \\
{\mathrm{He} \text { 3s-pig 3p-aloneness 3s.OBJ:hit-REAL-3s.SBJ-then=PAUS }} \\
{\text { 'he killed his pig alone (without anyone else involved)' }}
\end{aligned}
$$

Culturally, this term is used in occasions like a wedding ceremony whereby the bridegroom must hand over all the required items of the bridal price to the father (represented by the mother's brother) of his bride:

$$
\begin{aligned}
& \text { at ambek wanbanuk wokirak-o. } \\
& \text { at } \varnothing \text {-ampek wan-ban-uk wot-k-it-ak=ol } \\
& \text { he 3s-without gather-put down-next 3s.OBJ:give-REAL-3s.SBJ-then=PAUS } \\
& \text { 'having presented, he himself gave then...' or 'he himself, having presented, he } \\
& \text { gave then...' }
\end{aligned}
$$

[see also Text 35: 2.49-50; Burung 2013a: 241, 250-1]

\section{CONCLUSIONS}

In this chapter, I have discussed nominal properties found in Wano by focusing on its alienable and inalienable nouns. In $\S 1$, I set out several ways of looking at how alienable nouns and inalienable nouns are different. The conclusion was, firstly, that regarding their generalisation, alienable nouns are not found as abstract nouns, while inalienable nouns are not found as proper nouns (§2.1); secondly, that alienable nouns are both C-initial and V-initial, whilst inalienable nouns are limited to V-initial words (\$2.2); thirdly, that alienable nouns have no pluralisation, whereas inalienable nouns are pluralised by suffixation ( $\$ 2.3)$; fourthly, that with respect to their possessive structure, alienable nouns are prefixal vowel insertion, while inalienable nouns are vocalic bound prefixes (\$2.4); and fifthly, that while both nouns may be the head of a noun phrase, only inalienable nouns may play a role as the head of a clause.

A detailed discussion on inalienable nouns was provided in $\$ 4$. Four types of inalienable nouns were discussed: cultural items (§4.1), kin terms (§4.2), body parts $(\S 4.3)$ and experiential events (\$4.4). Sex distinction that is based on the possessor regarding terms for 'child' was explored, i.e. abut 'his child' is the term used only for male possessors, and ayak 'her child' is used only for female possessors. Hence, morphological paradigms with their semantic 
interpretations were provided to better understand Wano social interaction through its grammar. In $\S 4.4$, I briefly introduced the notion of experiential events, for which inalienable nouns may function as the head of a clause - see the example in (47). Some words are morphologically structured as inalienable nouns. They denote beneficiary and comitative-abessive expressions and were discussed in $\S 5$.

\section{NOTES}

*This paper reflects a section of my research thesis (2017). My sincere gratitude goes to Mary Dalrymple, Wolfgang de Melo, Peter Austin and anonymous reviewers; any shortcomings in this paper are entirely mine. $\$ 4.2$ was presented at the International Congress of MLI in Bali, 24-27 August 2016. The research was funded by Clarendon Fund Scholarship, University of Oxford. Costs to attend the congress, by St. Catherine's College and the Faculty of Linguistics, Philology and Phonetics, University of Oxford.

\section{REFERENCES}

Bromley, H. M. (1973). Ethnic groups in Irian Jaya, Irian 2-3. Jayapura: Cenderawasih University and Summer Institute of Linguistics Press.

Burung, W. (1993). Structures of oral texts in Wano: Data collected by Willem Burung since 1993. Unpublished manuscript.

. (1994). Paradigm of some verbs in Wano. Unpublished manuscript.

(1997). Translating kinship terms in Wano. Paper presented at the United Bible Societies Triennieal Translation Work. Merida, Mexico: United Bible Society of Mexico.

. (2001). Wano mini dictionary. Unpublished manuscript.

. (2002). Experiential-events in Wano. Proceeding, Australian Linguistics Society Annual Conference, Sydney: University of New South Wales and Macquarie University, 13-15 July 2002.

. (2003). Morpho-syntactic properties of experiential-events. Proceeding, Australian Linguistics Society Annual Conference, New Castle: University of New Castle, 26-28 September 2003.

. (2004). Experiential-events in Wano. Paper presented at the South-Pacific Summer Institute of Linguistics. Revision of Burung (2002). Kangaroo Ground: South Pacific SIL, 4 June 2004.

. (2005). Conjugational forms of wat-. Unpublished manuscript.

. (2007a, 2004). Experiential-events in Wano. Unpublished manuscript.

. (2007b). Translating kinship terms in Wano. URL: http:forestfriendlyfestchrift. blogspot.com/. Lembaga Alkitab Indonesia.

. (2007b, 2004). The phonology of Wano. SIL Electronic Working Papers. URL: http://www.sil.org/silewp/abstract.asp?ref=2007-2003/. 
. (2013). Elevative deixis in Wano: Exploring human social cognition in grammar. Paper presented at the International Conference on Languages in Papua, Manokwari: Center of Endangered Languages Documentation and Universitas Negeri Papua, January 2013.

. (2017). A grammar of Wano (Doctorate thesis). Oxford: Faculty of Linguistics, Philology and Phonetics, University of Oxford.

(forthcoming). Deixis in Wano.

Foley, W. A. (1986). The Papuan languages of New Guinea. Cambridge: Cambridge University Press.

. (1997). Anthropological linguistics: An introduction. Oxford: Blackwell Publishers.

Grimes, B. F. (ed.). (1996, 1994). Ethnologue: Languages of the world. Dallas: Summer Institute of Linguistics Inc.

Larson, G. F. (1977). Reclassification of Irian Jaya highlands language families: A lexicostatistical cross family sub-classification with historical implication, in Irian 6-2 (pp. 3-40). Jayapura: University of Cenderawasih.

Walker, R. and M. Moxness. (1988). Wano survey report. Unpublished manuscript.

\footnotetext{
i Papua was known as Nederlands Nieuw Guinea before 1963, then Irian Barat after 1963 and Irian Jaya soon after the year till now.

ii Symbols and abbreviations follow the Leipzig Glossing Rules (2003) list. Those are not found in the list are taken from Burung (2017), which are: AN 'abstract nouns', CM 'common nouns', CN 'countable nouns', CON 'concrete nouns', DSEQ 'delayed sequential', ft. 'free translation in English', GREF 'general reference', ISEQ 'immediate sequential', lit. 'literal translation', MN 'mass nouns', N/A 'not applicable', oDS 'of different sex', of 'of female', oM 'of male', oss 'of same sex', PAUS 'pausal', PN 'proper nouns', PROG 'progressive', Q 'question', s/p 'singular/plural for personal pronouns', SG/PL 'nominal singular/plural', SREF 'specific reference', * 'semantic-pragmatically unacceptable', $\varnothing$ 'zero morpheme', - 'morpheme break', 'compounding break', = 'clitic break', $\{\ldots\}$ 'morphological structure or morphological representation', $\backslash \ldots$. 'morphophonological meaning', <...> 'semantic interpretation', "..." 'semantic reading', '...' 'free translation in English', and [...] 'semantic-pragmatic explanation/restriction and or term usage'.
} 